\title{
2. Characterisation of the endemic Sulawesi Lenomys meyeri (Muridae, Murinae) and the description of a new species of Lenomys
}

\author{
Guy G Musser
}

\section{Introduction}

In 1969, DJ Mulvaney sent me a batch of subfossils excavated by him and his colleagues from caves and rock-shelters in the Makassar region of Sulawesi (Mulvaney and Soejono, 1970). Among them are samples from a cave (Leang Burung 1) containing examples of Lenomys meyeri, a large-bodied rat endemic to Sulawesi, and a single right dentary with an intact molar row that is from a smaller-bodied Lenomys, which represents a new species. The small Lenomys along with specimens of $L$. meyeri were excavated from a level with a radiocarbon date of $2820 \pm 210 \mathrm{BP}$, and other examples of L. meyeri were found in an underlying stratum dated at $3420 \pm 400 \mathrm{BP}$ (Mulvaney and Soejono, 1970: 171).

Here I name and describe the new Lenomys within the context of first characterising L. meyeri by briefly summarising external, cranial, dental, and other traits, sketching its geographic and elevational distributions based upon the small available samples, looking into geographic variation of cranial and dental morphometrics, and providing notes on ecology. The phylogenetic relationships of Lenomys to other murids will not be explored here.

\section{Materials and methods}

Specimens examined (mostly museum study skins and their associated skulls) are stored in the following institutions: the American Museum of Natural History, New York (AMNH); Natural History Museum (formerly British Museum of Natural History), London (BMNH); Museum Zoologicum Bogoriense, Cibinong, Java (MZB; now the Indonesian National Museum of Natural History); Naturhistorisches Museum Basel, Switzerland (NMB); Nationaal Museum of 
Natural History Naturalis (formerly the Rijksmuseum van Natuurlijke Historie), Leiden (RMNH); and National Museum of Natural History, Smithsonian Institution, Washington, DC (USNM).

External measurements were either taken by me or transcribed from collector's notations on skin labels: total length; length of tail (LT); length of hind foot, including claw (LHF); length of ear, from notch to crown (LE); and body weight or mass (W). Length of head and body (LHB) was derived by subtracting tail length from total length.
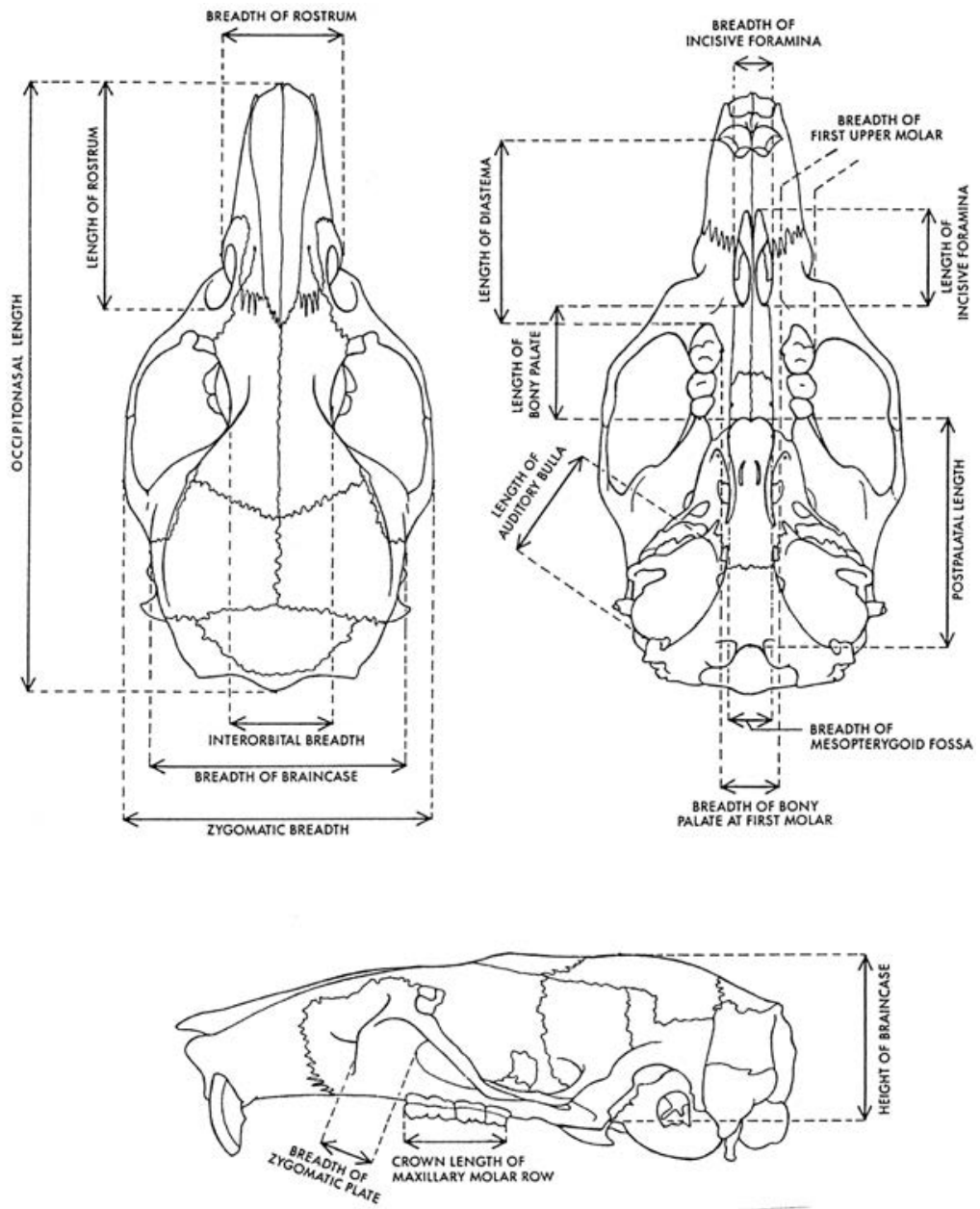

Figure 2.1: An adult Bunomys chrysocomus skull illustrating limits of cranial and dental measurements employed. See text for additional definitions.

Source: Drawing by Patricia Wynne. 
Using dial calipers graduated to tenths of a millimetre, I measured the following cranial and dental dimensions (illustrated in Figure 2.1):

$O N L=$ occipitonasal length (greatest length of skull; distance from tip of nasals to posterior margin of occiput)

$Z B=$ zygomatic breadth (greatest breadth across zygomatic arches)

$I B=$ interorbital breadth (least distance across the frontal bones between the orbital fossae)

$L R=$ length of rostrum (from tip of nasal bones to posterior margin of zygomatic notch)

$B R=$ breadth of rostrum (greatest breadth across rostrum, including bony nasolacrimal capsules)

$B B C=$ breadth of braincase (measured from just above the squamosal root of each zygomatic arch)

$H B C=$ height of braincase (from top of braincase to ventral surface of basisphenoid)

$B Z P=$ breadth of zygomatic plate (distance between anterior and posterior edges of zygomatic plate)

$L D=$ length of diastema (distance from posterior alveolar margins of upper incisors to anterior alveolar margin of $\mathrm{Ml}$ )

$P P L=$ postpalatal length (distance from posterior margin of palatal bridge to posterior edge of basioccipital - ventral lip of foramen magnum)

$L B P=$ length of bony palate (distance from posterior edge of incisive foramina to posterior margin of bony palate)

$B B P=$ breadth of bony palate at Ml (least distance between lingual alveolar margins of first molars)

$L I F=$ length of incisive foramina (distance from anterior to posterior margins)

$B I F=$ breadth across incisive foramina (greatest distance across both foramina)

$B M F=$ breadth of mesopterygoid fossa (distance from one edge of mesopterygoid fossa to the other)

$L B=$ length of ectotympanic (auditory) bulla (greatest length of bullar capsule, excluding the bony eustachian tube) 
CLM1-3 = crown length of maxillary molar row (from anterior enamel face of M1 to posterior enamel face of M3)

alm1-3 = alveolar length of mandibular molar row (from anterior alveolar rim of $\mathrm{ml}$ to posterior alveolar rim of $\mathrm{m} 3$ )

clm1-3 = crown length of mandibular molar row (from anterior enamel face of $\mathrm{ml}$ to posterior enamel face of $\mathrm{m} 3$ )

$B M 1=$ breadth of first maxillary (upper) molar (taken across widest part of molar)

$b m 1, b m 2, b m 3=$ breadths of first, second and third mandibular (lower) molars (taken across widest part of molar).

$M=$ maxillary (upper) molars

$M=$ mandibular (lower) molars

Cranial and dental measurements were obtained only from adults: animals clothed in adult pelage with occlusal surfaces of molars expressing the range from slight (young adults) to moderate (adults) to well worn where cusp patterns are nearly obliterated (old adults). Sexes were not separated in any of the statistical analyses because of the small number of specimens in each geographic sample. Furthermore, weak sexual dimorphism in cranial and dental variables generally characterises nongeographic sexual variation among muroid rodents (Musser, 2014; Musser and Durden, 2014).

Standard univariate descriptive statistics (mean, standard deviation, and observed range) were calculated for samples containing modern and fossil examples of $L$. meyeri and the new species. Principal-component analyses were computed using original cranial and dental measurements transformed to natural logarithms. Principal components were extracted from a variancecovariance matrix; loadings (correlations) of the variables are given as Pearson product-moment correlation coefficients of the extracted principal components. Probability levels denoting significance of the correlations are unadjusted. The statistical packages in SYSTAT 11 for Windows, Version 11 (2005), were used for all analytical procedures. 


\section{Gazetteer and specimens}

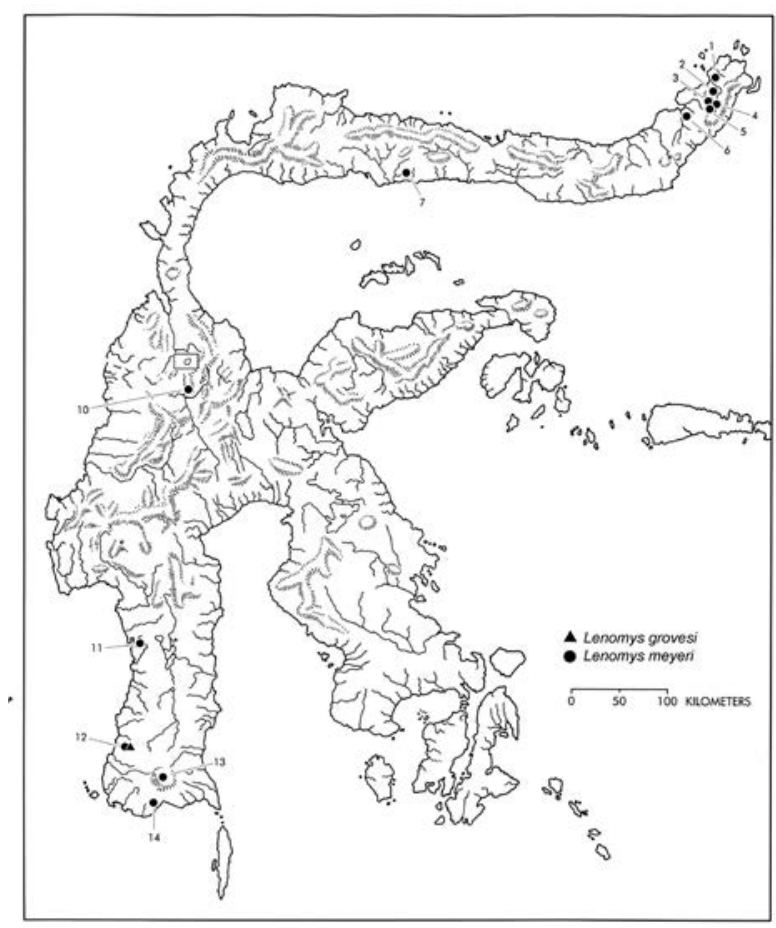

Figure 2.2a: Collection localities for modern and subfossil samples of Lenomys meyeri. Numbers key to localities described in the gazetteer. The map in Figure 2.2b contains collection localities 8 and 9. Locality 12 designates Leang Burung 1, the cave where subfossil dentaries of $L$. meyeri and $L$. grovesi $\mathrm{n}$. sp. were excavated (see gazetteer); the other subfossils come from caves and rock-shelters at locality 14. The Tempe Depression mentioned in text is at about the level of Parepare (locality 11).

Notes: Sulawesi consists of a central region from which four arms or peninsulas radiate: the northern peninsula, which ends in a northeastern jog; the eastern peninsula; the southeastern peninsula; the southwestern peninsula. I use these informal labels when describing the distribution of Lenomys, and refer to the central portion as Sulawesi's core. I also use the Indonesian names for mountain (Gunung), stream or river (Sungai), and lake (Danau).

Source: Drawing by Patricia Wynne. 


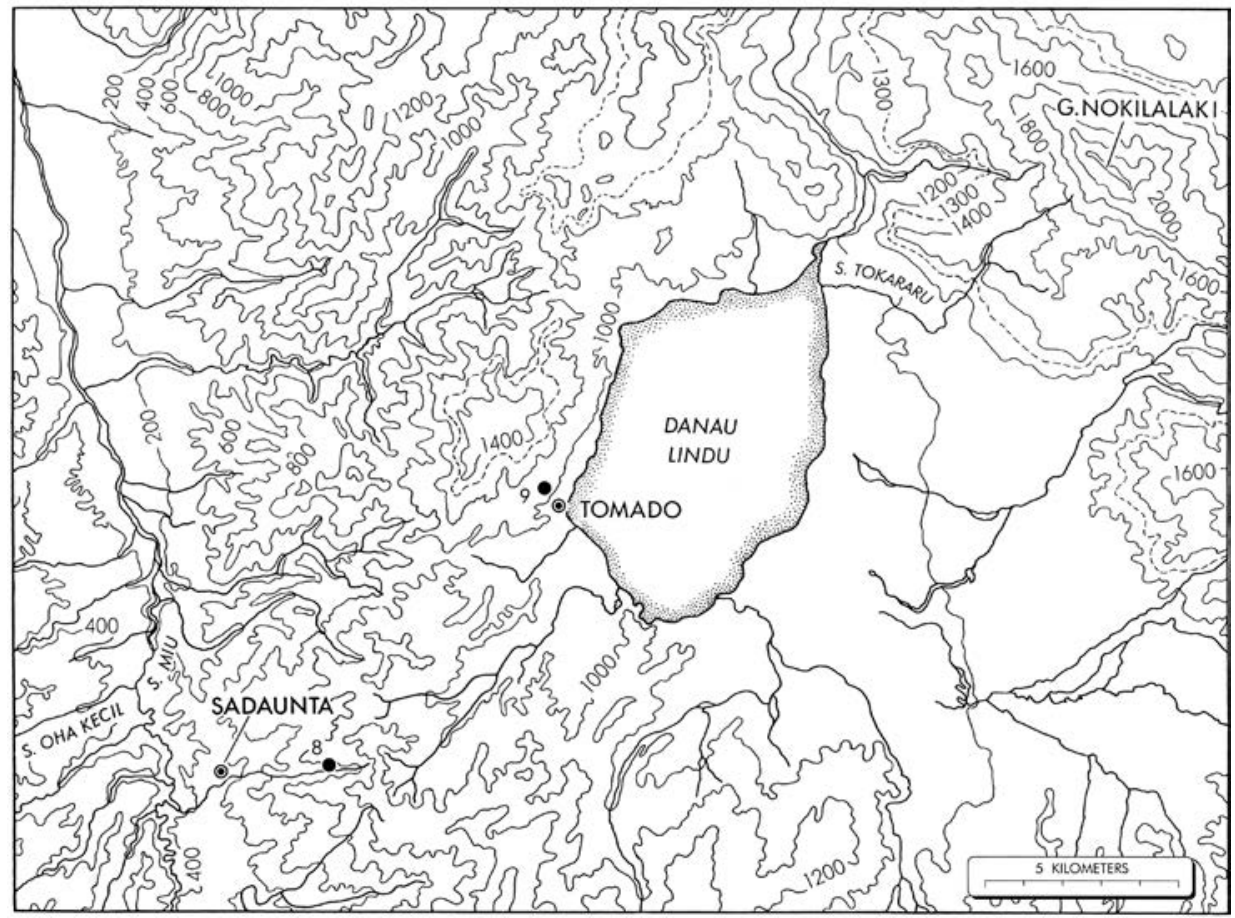

Figure 2.2b: Collection localities for modern and subfossil samples of Lenomys meyeri. Numbers key to localities described in the gazetteer. The map in Figure 2.2b contains collection localities 8 and 9; dashed contour line at $1300 \mathrm{~m}$ marks approximate boundary between tropical lowland evergreen and tropical lower montane rainforests.

Notes: Sulawesi consists of a central region from which four arms or peninsulas radiate: the northern peninsula, which ends in a northeastern jog; the eastern peninsula; the southeastern peninsula; the southwestern peninsula. I use these informal labels when describing the distribution of Lenomys, and refer to the central portion as Sulawesi's core. I also use the Indonesian names for mountain (Gunung), stream or river (Sungai), and lake (Danau).

Source: Drawing by Patricia Wynne.

Listed below are the localities at which the 27 modern and 20 subfossil specimens of Lenomys meyeri I examined were collected. The number preceding each place keys to the same numbered locality on the maps in Figures 2.2a and 2.2b. Cartographic and gazetteer sources for latitudes, longitudes, and spellings are referenced in Musser and others (2010).

1. Manado, $01^{\circ} 30^{\prime} \mathrm{N}, 124^{\circ} 50^{\prime} \mathrm{E}$, coastal plain near sea level: RMNH 21233 .

2. Rurukan, $01^{\circ} 21^{\prime} \mathrm{N}, 124^{\circ} 52^{\prime} \mathrm{E}, 3500 \mathrm{ft}(1067 \mathrm{~m})$ : BMNH 97.1.2.19.

3. Gunung Masarang, $01^{\circ} 19^{\prime} \mathrm{N}, 124^{\circ} 51^{\prime} \mathrm{E}, 3800 \mathrm{ft}(1159 \mathrm{~m})$ : BMNH 97.1.2.20. 
4. Tomohon, $01^{\circ} 19^{\prime} \mathrm{N}, 124^{\circ} 49^{\prime} \mathrm{E}, 700-800 \mathrm{~m}$ BMNH 99.10.1.9; NMB 1208, 3326, $3327,1110 / 4759$.

5. Langoon, $01^{\circ} 09^{\prime} \mathrm{N}, 124^{\circ} 50^{\prime} \mathrm{E}, 700-800 \mathrm{~m}$ : RMNH 18302 (holotype of Mus meyeri).

6. Amurang, $01^{\circ} 11^{\prime} \mathrm{N}, 124^{\circ} 35^{\prime} \mathrm{E}$, coastal plain near sea level: BMNH 21.2.9.4; MZB 384, 5810 .

7. Bumbulan, $00^{\circ} 29^{\prime} \mathrm{N}, 122^{\circ} 04^{\prime} \mathrm{E}$, coastal plain near sea level: AMNH 153011 .

8. Valley of Sungai Miu, Sungai Sadaunta, $01^{\circ} 23^{\prime} \mathrm{S}, 119^{\circ} 58^{\prime} \mathrm{E}, 3000 \mathrm{ft}(915 \mathrm{~m})$ : AMNH 226813, 226814.

9. Valley of Danau Lindu, forest near Tomado (a village on western shore of Danau Lindu), $01^{\circ} 19^{\prime} \mathrm{S}, 120^{\circ} 03^{\prime} \mathrm{E}, 1000 \mathrm{~m}$ : AMNH 224317.

10. Gimpu, $01^{\circ} 36^{\prime} \mathrm{S}, 120^{\circ} 02^{\prime} \mathrm{E}, 400 \mathrm{~m}$ : USNM 219712 (holotype of Lenomys longicaudus).

11. Parepare, $04^{\circ} 01^{\prime} \mathrm{S}, 119^{\circ} 38^{\prime} \mathrm{E}$, coastal plain near sea level: RMNH 18303. This is the cranium discussed, figured, and identified as Mus callitrichus by Jentink (1890: pl. 10, Figures 4-6, Plate 120).

12. Leang Burung 1, a cave near the village of Pakalu, 'about $2 \mathrm{~km}$ north of the main road from Maros, $10 \mathrm{~km}$ to the west' (Mulvaney and Soejono, 1970: 169), less than 100 m: AMNH 265022-265028 (subfossils). The dentary of Lenomys grovesi n. sp. was also collected here (Table 2.8).

13. Wawokaraeng, Gunung Lompobatang, an extinct volcanic mountain near the tip of the southwestern peninsula, 05 ${ }^{\circ} 20^{\prime} \mathrm{S}, 1^{\circ} 9^{\circ} 55^{\prime} \mathrm{E}$ : $2200 \mathrm{~m}$, AMNH 101125 , 101127, 101128 (holotype of Lenomys meyeri lampo), 101129; 2300 m, AMNH $101126 ; 2400$ m, ANMH 101124.

14. Panganreang Tudea, a rock shelter at the southern tip of the southwestern peninsula (see description and map in Mulvaney and Soejono, 1970: 166): subfossil Specimen Numbers 2-10 documented by Musser (1984). Batu Ejaja, a cave 'a few hundred meters distant' from Panganreang Tudea (Mulvaney and Soejono, 1970: 166), 275 m: subfossil Specimen Number 1 documented by Musser (1984). Batu Edaja 2, a rock shelter near Batu Edjaja (see description Mulvaney and Soejono, 1970): AMNH 265029-265031 (subfossils).

The following specimens were examined but their provenances were not mapped:

A. Minahassa, Warumbungan: RMNH 2797. 
B. RMNH 18304; a skull listed as specimen 'c' under 'Mus giganteus' in Jentink's 'Catalogue Ostéologique des Mammifères', published in 1887 (p. 210); 'Java' is listed as provenance, but the skull is Lenomys meyeri.

\section{Lenomys (Thomas, 1898)}

The mounted skin and partial skull shown in Figures 2.3 and 2.4 are the basis for Jentink's (1879: 12-13) short and undiagnostic description of Mus meyeri. Later, Thomas (1898: 409) recognised the distinctive attributes of meyeri, proposed the genus Lenomys to contain it, and provided a diagnosis that applies to the genus and to L. meyeri. The characterisation of L. meyeri follows.

\section{Lenomys meyeri (Jentink, 1879)}

Mus meyeri Jentink, 1879: 12.

Lenomys longicaudus Miller and Hollister, 1921b: 5.

Lenomys meyeri lampo Tate and Archbold, 1935b: 5.

\section{Holotype and type locality}

The holotype is RMNH 18302; the skin and skull of an adult (sex not determined) obtained in September 1875 by SCIW van Musschenbroek, and is listed as specimen ' $a$ ' in Jentink's (1888: 65) 'Catalogue Systématique des Mammifères'. External, cranial, and dental measurements, along with other relevant data, are listed in Table 2.2.

The skin is mounted in a pose meant to simulate the living rat (Figure 2.3); the fur is discoloured, a straw-brown. The cranium is incomplete: pieces of nasals and right zygomatic arch, and ventral and occipital portions of the braincase are missing (Figure 2.4). Except for worn angular processes, the mandible is intact. All incisors and molars are present and undamaged.

The type locality is Langoon $\left(01^{\circ} 09^{\prime} \mathrm{N}, 124^{\circ} 50^{\prime} \mathrm{E}\right), 700-800 \mathrm{~m}$ (locality 4 in gazetteer and Figure 2.2a), northeastern tip of the northern peninsula, Propinsi Sulawesi Utara, Indonesia. Jentink (1879: 13) noted the 'habitat' to be 'Celebes, Menado', but information attached to the holotype indicates it came from 'Menado, Langowan' (now spelled Langoon). 


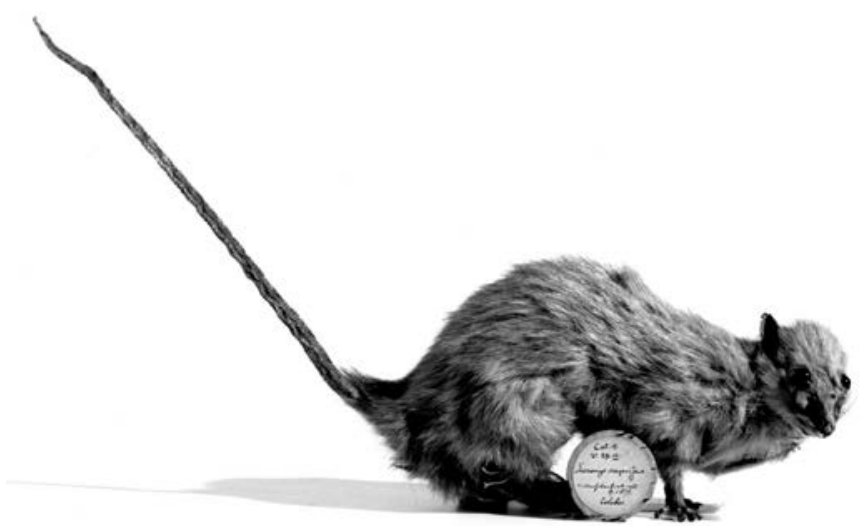

Figure 2.3: Holotype of Mus meyeri (RMNH 18302; listed as specimen ' $a$ ' in Jentink's [1888: 65] 'Catalogue Systématique des Mammifères'). Measurements are listed in Table 2.2.

Source: Photograph by Peter Goldberg.
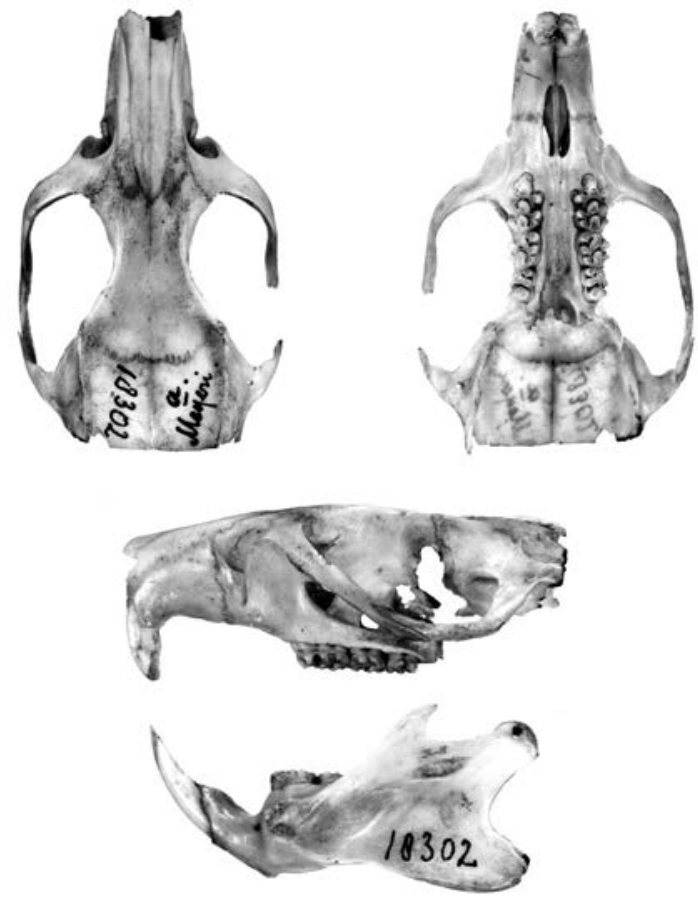

Figure 2.4: Skull of the holotype of Mus meyeri (RMNH 18302. See Table 2.2 where measurements are listed. X2

Source: Photograph by Peter Goldberg. 


\section{Geographic and elevational distributions}

Because provenances of specimens are few and scattered, the actual range of $L$. meyeri is unknown; most samples are from the northeastern tip of the northern peninsula and the southern end of the southwestern peninsula (Figure 2.2a). While broad swaths of Sulawesi, including all of the eastern and southeastern peninsulae as well as most of the central portion, are without records of L. meyeri, I suspect its range extends over most of Sulawesi wherever suitable forest habitats remain.

Modern specimens from north of the southwestern peninsula have been collected from the coastal plain near sea level to 1,159 m, an elevational range in which tropical lowland evergreen rainforests dominate, or at least did in the past (I use Whitmore's [1984] terminology for forest formations). Maryanto and others (2009: 47) record a specimen of 'Lenomys meyeri' from about 2,100 $\mathrm{m}$ in 'cloud forest' in Lore Lindu National Park, which is in the northern section of central Sulawesi. I had worked in the same region but obtained L. meyeri only at lower elevations in tropical lowland evergreen rainforest, and Eropeplus canus, which externally closely resembles Lenomys, only high in mountain forest; I suspect their specimen is an example of E. canus.

South of the Tempe Depression (the swampy and lake-filled lowlands bisecting the peninsula at its northern margin at about the latitude of Parepare), examples of $L$. meyeri are represented by subfossils excavated from caves in lowlands (100-275 m) and modern samples obtained in montane forest at 2,200-2,400 m on Gunung Lompobatang - the only place where the species is accurately recorded from montane forest habitats.

Table 2.1: Descriptive statistics for measurements of lengths of head and body, tail, hind foot, and ear, and for weight, derived from modern samples of Lenomys meyeri.

\begin{tabular}{|l|r|r|r|r|}
\hline \multicolumn{1}{|c|}{ Variable } & \multicolumn{1}{|c|}{ Northeast } & Northcentral & Core & Southwest Peninsula \\
\hline LHB & $\begin{array}{r}281.5 \pm 13.63 \\
(270-301) 4\end{array}$ & 256 & $\begin{array}{r}253.3 \pm 16.80 \\
(235-268) 3\end{array}$ & $\begin{array}{r}265.7 \pm 11.34 \\
(245-275) 6\end{array}$ \\
\hline LT & $\begin{array}{r}277.4 \pm 2.51 \\
(275-280) 5\end{array}$ & 242 & $\begin{array}{r}270.7 \pm 10.07 \\
(260-280) 3\end{array}$ & $\begin{array}{r}277.3 \pm 19.74 \\
(240-298) 6\end{array}$ \\
\hline LT/LHB (\%) & 99 & 95 & 107 & 104 \\
\hline LHF & $\begin{array}{r}47.2 \pm 0.84 \\
(46-48) 5\end{array}$ & 47 & $\begin{array}{r}47.7 \pm 1.53 \\
(46-49) 3\end{array}$ & $\begin{array}{r}48.2 \pm 1.72 \\
(46-50) 6\end{array}$ \\
\hline LE & - & 28 & $\begin{array}{r}27.0 \pm 1.41 \\
(26-28) 2\end{array}$ & $\begin{array}{r}26.3 \pm 1.51 \\
(24-28) 6\end{array}$ \\
\hline W & - & - & $\begin{array}{r}322.5 \pm 3.54 \\
(320-325) 2\end{array}$ & - \\
\hline
\end{tabular}


Notes: Measurements are in millimetres, weight in grams. Mean $\pm 1 \mathrm{SD}$, observed range (in parentheses), and size of sample are listed. Mean values were used to compute LT/LHB. Variable abbreviations are defined in the text. Specimens measured are listed below:

Northeast - Amurang: BMNH 21.2.9.4, MZB 5810. Gunung Masarang: BMNH 97.1.2.20. Rurukan: BMNH 97.1.2.19. Langowan: RMNH 18302 (holotype of Mus meyeri). All were measured by collectors other than me.

Northcentral - Bumbulan: AMNH 153011 (measured by JJ Menden).

Core - Sadaunta: AMNH 226813. Tomado: AMNH 224317 (these two were measured by me). Gimpu: USNM 219712 (holotype of Lenomys longicaudus; measured by HC Raven).

Southwest Peninsula - Gunung Lompobatang: AMNH 101124-27, 101128 (holotype of Lenomys meyeri lampo), 101129 (all measured by G Heinrich)

Source: Author's data.

Table 2.2: Age, sex, number of teats, and external, cranial, and dental measurements for holotypes associated with Lenomys meyeri.

\begin{tabular}{|c|c|c|c|}
\hline & $\begin{array}{l}\text { Mus meyeri } \\
\text { RMNH } \\
18302 \\
\end{array}$ & $\begin{array}{c}\text { Lenomys longicaudus } \\
\text { USNM } \\
219712 \\
\end{array}$ & $\begin{array}{c}\text { Lenomys meyeri lampo } \\
\text { AMNH } \\
101128 \\
\end{array}$ \\
\hline Age & Adult & Adult & Adult \\
\hline Sex & $?$ & Female & Female \\
\hline LHB & 275 & 235 & 275 \\
\hline$\overline{L T}$ & 280 & 260 & 276 \\
\hline LT/LHB (\%) & 102 & 111 & 100 \\
\hline LWS & 128 & 82 & 145 \\
\hline LWS/LT (\%) & 46 & 32 & 53 \\
\hline TSR/CM & 7 & 7 & 7 \\
\hline LHF & 46 & 48 & 47 \\
\hline$\overline{\mathrm{LE}}$ & - & - & 25 \\
\hline LDF & $20-25$ & $25-30$ & $25-30$ \\
\hline Teats & $?$ & 2 inguinal pairs & 2 inguinal pairs \\
\hline$\overline{O N L}$ & - & 56.2 & 57.2 \\
\hline $\mathrm{ZB}$ & 27.5 & 27.1 & 28.2 \\
\hline IB & 7.5 & 7.3 & 7.0 \\
\hline LR & - & 15.7 & 17.4 \\
\hline$\overline{B R}$ & 10.1 & 10.3 & 9.6 \\
\hline $\mathrm{BBC}$ & - & 19.3 & 18.7 \\
\hline $\mathrm{HBC}$ & - & 14.4 & 13.5 \\
\hline BZP & 6.5 & 5.6 & 6.1 \\
\hline LD & 13.1 & 13.9 & 16.0 \\
\hline PPL & - & 19.2 & 19.0 \\
\hline LBP & 14.4 & 14.4 & 14.8 \\
\hline $\mathrm{BBP}$ & 2.6 & 2.8 & 3.1 \\
\hline BMF & 3.5 & 3.3 & 3.0 \\
\hline LIF & 7.3 & 6.9 & 9.1 \\
\hline $\mathrm{BIF}$ & 2.8 & 2.8 & 3.0 \\
\hline LB & - & 7.8 & 8.8 \\
\hline CLM1-3 & 12.1 & 10.8 & 11.0 \\
\hline BM1 & 3.5 & 3.2 & 3.3 \\
\hline
\end{tabular}

Notes: Measurements are in millimetres. Unless otherwise indicated, I copied from skin tags the values for external measurements; I measured the cranial and dental dimensions. Variable acronyms are defined in the text. 
Taxonomic Tapestries

For the holotype of meyeri, I measured lengths of head and body, tail, and white tail segment on the mounted skin. In the original description of RMNH 18302, Jentink listed $290 \mathrm{~mm}$ and $270 \mathrm{~mm}$, respectively, for lengths of head and body and tail. For the holotype of longicaudus, I measured lengths of tail, white tail segment, and hind foot on the stuffed museum study skin; $280 \mathrm{~mm}$ for the tail and $45 \mathrm{~mm}$ for the hind foot are recorded on the skin label.

Number of scale rings per centimetre on the tail (TSR/CM) was counted about one-third the distance from its base.

To measure lengths of overfur and guard hairs on the dorsum (LDF), I placed a ruler at a right angle to the skin surface on the back near the rump and recorded the approximate mark where ends of the bunched hairs rested.

Source: Author's data.

\section{Description}

Adult Lenomys meyeri are physically large with a short and wide head, stocky body, small ears, and moderately long tail (LHB $=235-301 \mathrm{~mm}, \mathrm{LT}=240$ $298 \mathrm{~mm}, \mathrm{LHF}=46-50 \mathrm{~mm}, \mathrm{LE}=24-28 \mathrm{~mm}, \mathrm{~W}=320-325 \mathrm{~mm}$; Figure 2.5, Table 2.1). Fur covering upperparts is dense, woolly, soft, and long (length of underfur $=15-30 \mathrm{~mm}$, depending on elevation of provenance), with guard hairs extending 5-10 $\mathrm{mm}$ beyond the underfur layer; overall colour ranges from grayish brown to dark brownish gray and is without patterning except for brownish black areas at the base of the mystacial vibrissae. The dark dorsal coat extends onto the basal 50-55 $\mathrm{mm}$ of the tail. The small ears are dark gray or brownish gray and finally haired on the margins. Ventral coat is short (10$15 \mathrm{~mm}$ ) and grayish white (hairs with gray bases and unpigmented tips) or whitish gray. Tail is bicoloured, scantily haired, and ranges from being slightly shorter than length of head and body to slightly longer (LT/LHB $=95-107 \%$ ); scale hairs are moderately large (Table 2.2), each scale bearing three short hairs; basal portion of tail is dark brownish gray, distal $32-63 \%$ is white (Figure 6). Front and hind feet are short and broad; all dorsal surfaces (tarsal, metatarsal, and digital) are dark brown, claws are stout and unpigmented. Palmar and plantar surfaces are naked, unpigmented and adorned with large fleshy pads (three interdigitals, thenar and hypothenar on palmar surface; four interdigitals, thenar and hypothenar on plantar surfaces).

Females have two pairs of inguinal teats.

The cranium is large and stocky (Figure 2.7). Characteristic features are its short rostrum; stout zygomatic arches that bow widely out from sides of the rostrum and braincase; strong supraorbital ridges that transform posteriorly into postorbital shelves that extend posteriorly as pronounced temporal ridges all the way to the occiput where they fuse with the lamboidal ridges; trapezoidshaped interparietal; wide zygomatic plate; large premaxillary foramen, 
moderately short and wide incisive foramina; long, deeply scored bony palate; wide mesopterygoid region with moderately long and wide sphenopalatine vacuities; large ectotympanic bulla; and no alisphenoid strut.

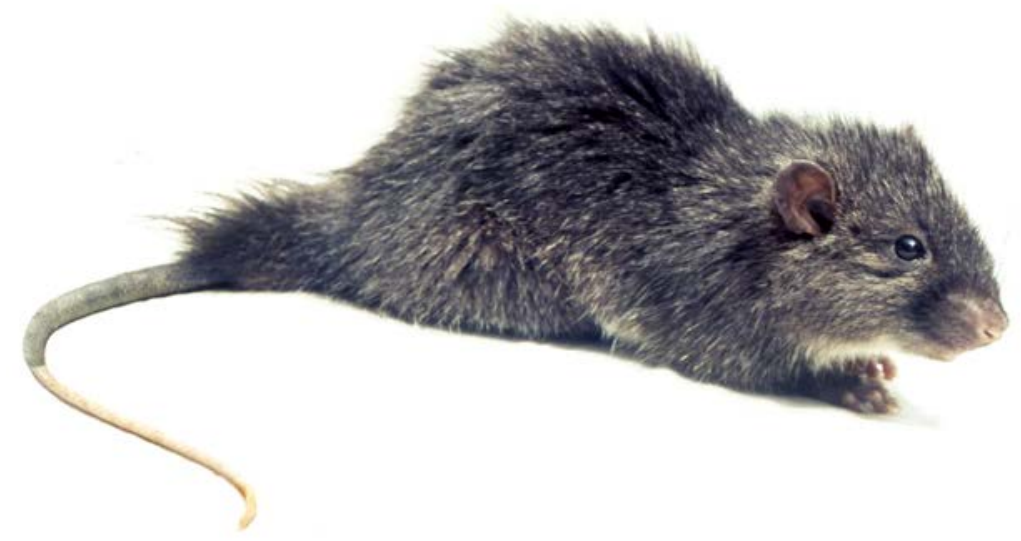

Figure 2.5: Young adult female Lenomys meyeri (AMNH 224317) from tropical lowland evergreen rainforest near Tomado, $1000 \mathrm{~m}$. Collected May 16, 1974.

Source: Photograph by Author.

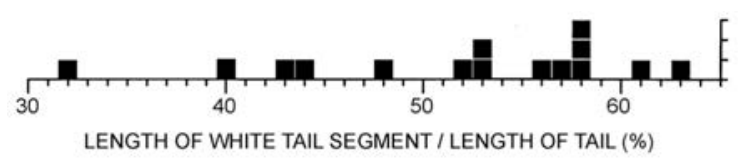

Figure 2.6: Length of distal white tail segment relative to total length of tail in the sample of Lenomys meyeri. I measured the distal white segment (in $\mathrm{mm}$ ) on freshly caught rats in the field and on dry museum preparations.

Source: Drawing by Patricia Wynne.

A carotid arterial circulation that is derived for muroid rodents in general but primitive for members of subfamily Murinae (character-state 2 of Carleton, 1980; pattern 2 described by Voss, 1988; diagrammed for Oligoryzomys by Carleton and Musser, 1989), is present in L. meyeri as indicated by the presence of a large stapedial foramen in the petromastoid fissure, a deep groove extending from the middle lacerate foramen to the foramen ovale on the ventral posterolateral surface of each pterygoid plate, and no sphenofrontal foramen or squamosalalisphenoid groove. Each robust dentary has a pronounced coronoid process and stout condyloid and angular processes; the ramus anterior to the molar row is short and thick. 
Incisors are broad and robust, enamel layers are orange in the uppers and pale orange in the lowers; uppers emerge from the rostrum at either a right angle or curve slightly back.

Maxillary (upper) and mandibular (lower) molars are robust, moderately highcrowned, with sharply defined large and high angular cusps, and only slight overlapping occurs between molars in each row (Figure 2.9). Typically, Ml is anchored by five roots, M2 by four, and M3 by three. The same pattern of roots is found on the lower molars, with the exception of AMNH 265022, in which $\mathrm{m} 4$ has five roots and $\mathrm{m} 3$ has four.

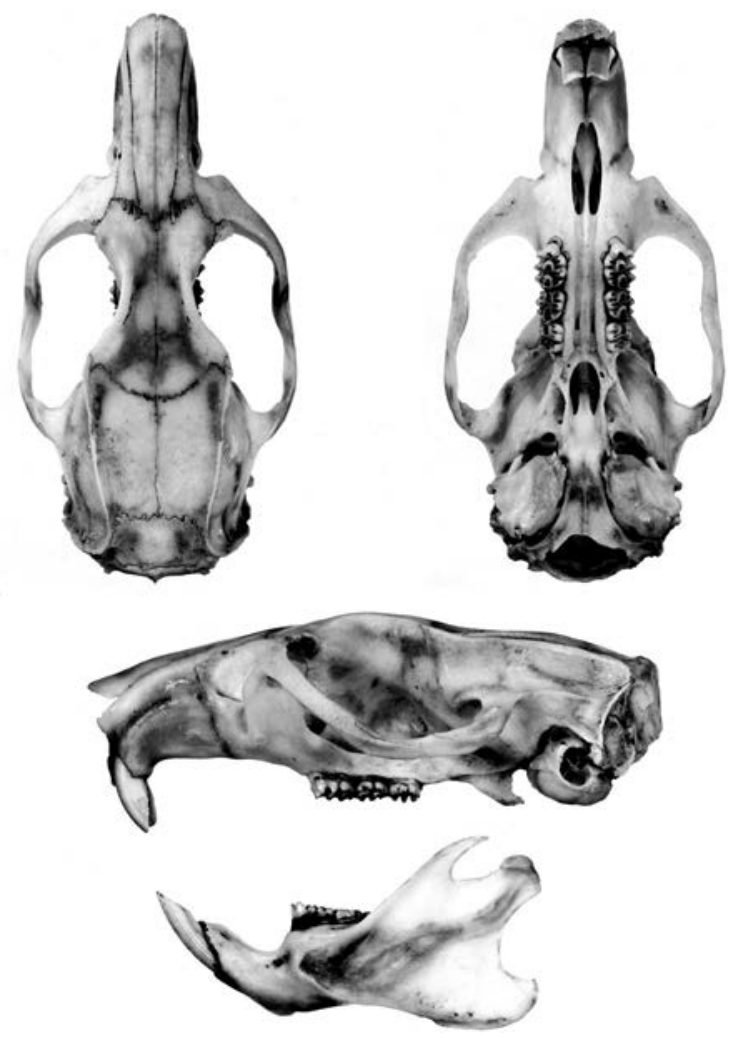

Figure 2.7: Cranium and left dentary of Lenomys meyeri lampo (AMNH 101128, the holotype), an adult female collected at $2200 \mathrm{~m}$ on Gunung Lompobatang. X2.

Source: Photograph by Peter Goldberg. 


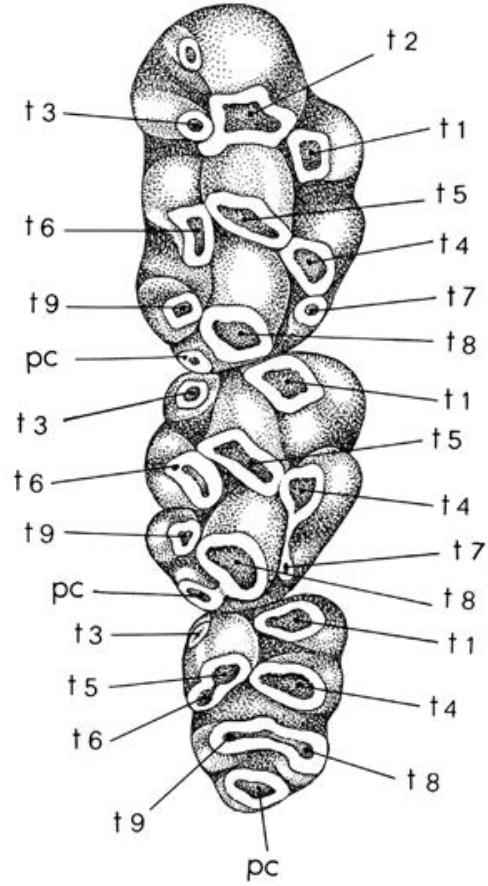

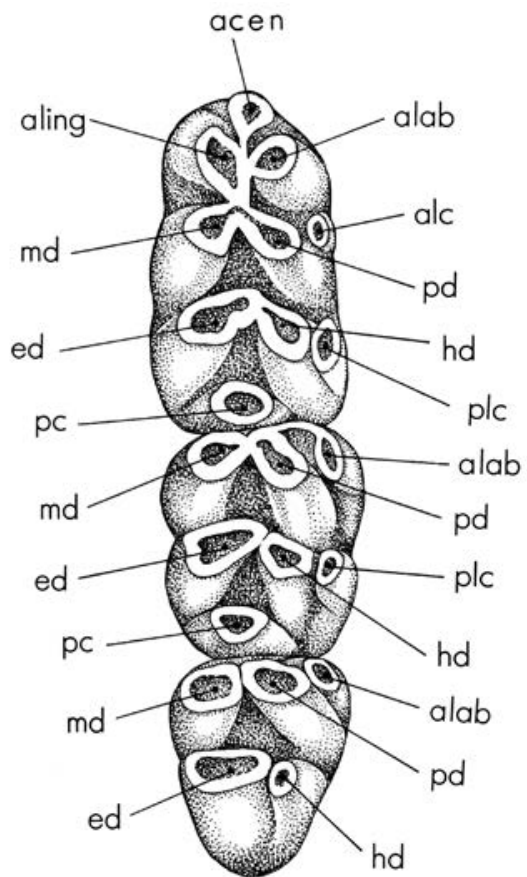

Figure 2.8: Nomenclature of dental structures using right upper and lower molars of Lenothrix canus. Maxillary molars: Cusps are numbered according to Miller's (1912) scheme and are referred to in the text with the prefix ' $t$ '; pc, posterior cingulum. Mandibular molars: The anterocentral cusp (acen), anterolabial cusp (alab), and anterolingual cusp (aling) form the anteroconid; an anterior labial cusplet (alc) is present on the first molar and posterior labial cusplets (plc) occur on all three teeth; primary cusp rows are formed by the protoconid (pd) and metaconid (md), and the hypoconid (hd) and entoconid (ed); a posterior cingulum (pc) sits at the back of first and second molars (adapted from van de Weerd, 1976: 44).

Source: Drawing by Patricia Wynne.

Occlusal cusp patterns seen in Lenomys are unique among endemic Sulawesi murids. Distinctive features of the maxillary molars, in addition to the tall and discrete cusps, are a prominent cusp $\mathrm{t} 7$ on all molars (indistinct on M3 in some specimens because it has partially fused with the adjacent cusp t8); a prominent cusp t3 on M2 and M3; a posterior cingulum that is a moderately large and discrete cusp on all molars of many specimens, but an enamel ridge or bump on other specimens; prominent crests (enamel and dentine) extending backwards from cusps $t 1$ and $t 3$ on M1, from cusp tl on M2, from cusps $t 4$ and t6 on Ml 
and M2 (stephanodonty; see Misonne, 1969: 55). In some specimens, the crests extending from cusps $t 4$ and $t 6$ merge with the anterior faces of cusps $t 7$ and t9 to form a circle consisting of cusps and crests on M1 and M2.
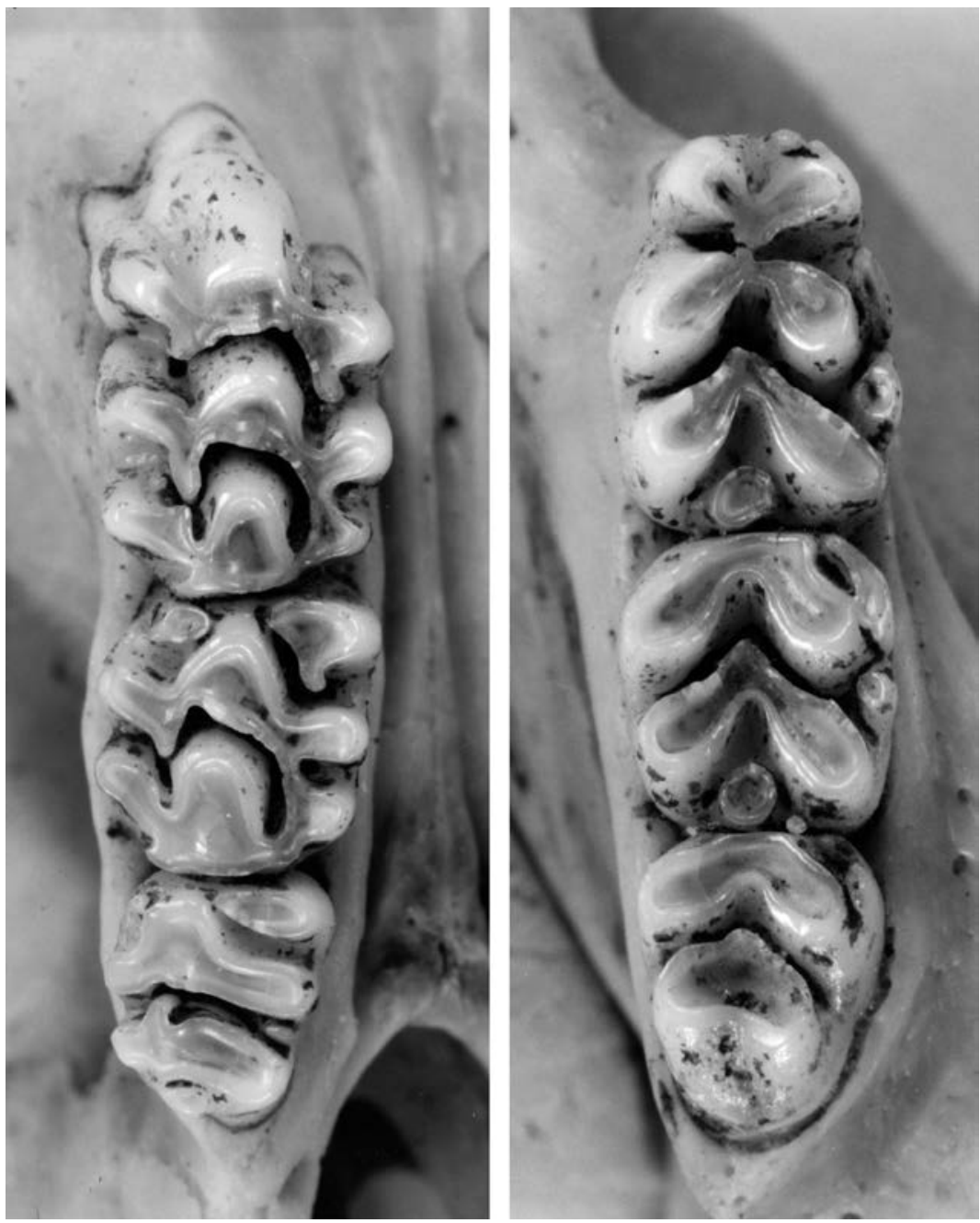

Figure 2.9: Occlusal views of right maxillary (left image) and mandibular (right image) molar rows of Lenomys meyeri (AMNH 101127) from Gunung Lompobatang. X10. See Figure 2.8 for cusp labels.

Source: Photograph by Peter Goldberg.

Occlusal cusp patterns of mandibular molars are equally distinctive (Figures 2.9, 2.15). In many specimens, a mid-sagittal enamel crest connects the anteroconid and the second cusp row, and that row is also connected with the posterior cusp row by a mid-sagittal crest in some specimens. In all specimens, the anteroconid 
is formed by two large and discrete cusps, and a small anterocentral cusp is present on some molars (Figure 2.15, centre) but absent from other specimens (Figure 2.15, right). Additional elaborations are anterior and posterior cusplets on $\mathrm{m} 1$, an anterolabial cusp and posterior labial cusplet on $\mathrm{m} 2$, an anterolabial cusp on $\mathrm{m} 3$, and prominent posterior cingula on $\mathrm{ml}$ and $\mathrm{m} 2$.

In addition to the cranial and dental traits summarised here, there is information covering spermatozoan morphology. The sperm head is symmetrical without hooks, and the spermatozoan tail is attached to the midbasal region of the head (Breed and Musser, 1991). Among the Sulawesian species of murines surveyed by Breed and Musser, only Eropeplus canus and Taeromys celebensis share similar morphologies.

\section{Geographic variation}

If there is more than one species in Lenomys, it is not clearly evident in the modern material at hand, which consists of small samples ( $1-6$ specimens) from widely separated localities (Figure 2.2). Variation in fur colour (upper parts range from grayish brown to dark brownish gray, underparts whitish gray to grayish white, dorsal fur thick and woolly to thinner and harsher) forms no apparent geographic pattern. Cranial and dental measurements suggest a pattern that must be substantiated by measurements from larger samples. The montane sample from Gunung Lompobatang averages a longer and wider skull (ONL and ZB), zygomatic plate (BZP) and bony palate (BBP); longer diastema (LD) and incisive foramina (LIF); and larger bullae (LB) than other geographic samples (Table 2.3). The variation is summarised by the distribution of specimen scores projected on first and second principal components in Figure 2.10. Size influences spread of the scores along the first axis (largest to the right), with loadings of the variables noted above being most forceful $(r=0.62-0.88)$ - the three scores for the Gunung Lompobatang series are farthest to the right. Long incisive foramina and large bullae were among the traits used by Tate and Archbold (1935: 5) to distinguish L. m. lampo. The cranium from Parepare (at the southern margin of the Tempe Depression) also has long incisive foramina (8.7 $\mathrm{mm}$ according to Hooijer, 1950: 76), thus falling within the range of the Lompobatang sample. Scatter of scores for the other specimens likely reflect individual and age variation within adults. For example, the points for specimens from the northeast (filled circle) are scattered along the first component and all are adults. Aside from the possible separation of the Gunung Lompobatang sample, no other apparent geographic pattern emerges from the analysis; samples, however, are small. A principal-component analysis (not illustrated) employing only dental variables, which allowed me to use the subfossil material, revealed no significant geographic pattern in dental measurements, and no separation of the Lompobatang toothrows. 
Taxonomic Tapestries

Table 2.3: Descriptive statistics for cranial and dental measurements derived from modern samples of Lenomys meyeri.

\begin{tabular}{|c|c|c|c|c|}
\hline Variable & $\begin{array}{l}\text { Northeast } \\
N=5\end{array}$ & $\begin{array}{l}\text { Northcentral } \\
N=1\end{array}$ & $\begin{array}{l}\text { Core } \\
N=2\end{array}$ & $\begin{array}{l}\text { Southwest Peninsula } \\
N=3\end{array}$ \\
\hline ONL & $\begin{array}{r}53.8 \pm 1.70 \\
(52.3-56.4)\end{array}$ & 54.8 & $\begin{array}{r}54.7 \pm 2.12 \\
(53.2-56.2)\end{array}$ & $\begin{array}{r}55.4 \pm 2.02 \\
(53.2-57.2)\end{array}$ \\
\hline ZB & $\begin{array}{r}27.0 \pm 1.06 \\
(25.8-28.4)\end{array}$ & 27.2 & $\begin{array}{r}26.6 \pm 0.71 \\
(26.1-27.1) \\
\end{array}$ & $\begin{array}{r}27.5 \pm 0.64 \\
(27.0-28.2)\end{array}$ \\
\hline IB & $\begin{array}{r}8.0 \pm 0.21 \\
(7.8-8.3)\end{array}$ & 8.0 & $\begin{array}{r}7.1 \pm 0.28 \\
(6.9-7.3)\end{array}$ & $\begin{array}{r}7.2 \pm 0.29 \\
(7.0-7.5)\end{array}$ \\
\hline LR & $\begin{array}{r}15.6 \pm 0.38 \\
(15.2-16.2)\end{array}$ & 16.1 & $\begin{array}{r}15.4 \pm 0.42 \\
(15.1-15.7) \\
\end{array}$ & $\begin{array}{r}15.9 \pm 1.50 \\
(14.4-17.4)\end{array}$ \\
\hline BR & $\begin{array}{r}10.1 \pm 0.30 \\
(9.7-10.4)\end{array}$ & 10.5 & $\begin{array}{r}10.2 \pm 0.14 \\
(10.1-10.3)\end{array}$ & $\begin{array}{r}9.6 \pm 0.25 \\
(9.4-9.9)\end{array}$ \\
\hline BBC & $\begin{array}{r}19.3 \pm 0.18 \\
(19.1-19.5)\end{array}$ & 18.9 & $\begin{array}{r}18.9 \pm 0.64 \\
(18.4-19.3)\end{array}$ & $\begin{array}{r}19.0 \pm 0.35 \\
(18.7-19.4)\end{array}$ \\
\hline $\mathrm{HBC}$ & $\begin{array}{r}13.4 \pm 0.45 \\
(12.8-14.0)\end{array}$ & 13.5 & $\begin{array}{r}14.1 \pm 0.49 \\
(13.7-14.4)\end{array}$ & $\begin{array}{r}13.7 \pm 0.25 \\
(13.5-14.0)\end{array}$ \\
\hline BZP & $\begin{array}{r}5.9 \pm 0.30 \\
(5.5-6.3) \\
\end{array}$ & 6.5 & $\begin{array}{r}5.8 \pm 0.28 \\
(5.6-6.0)\end{array}$ & $\begin{array}{r}6.2 \pm 0.36 \\
(5.9-6.6) \\
\end{array}$ \\
\hline LD & $\begin{array}{r}13.8 \pm 0.84 \\
(13.0-15.1)\end{array}$ & 15.1 & $\begin{array}{r}13.7 \pm 0.35 \\
(13.4-13.9)\end{array}$ & $\begin{array}{r}14.9 \pm 1.15 \\
(13.7-16.0)\end{array}$ \\
\hline PPL & $\begin{array}{r}19.8 \pm 0.35 \\
(19.4-20.2)\end{array}$ & 19.1 & $\begin{array}{r}19.5 \pm 0.42 \\
(19.2-19.8)\end{array}$ & $\begin{array}{r}19.7 \pm 1.02 \\
(19.0-20.9)\end{array}$ \\
\hline LBP & $\begin{array}{r}13.6 \pm 0.38 \\
(13.1-14.0)\end{array}$ & 13.0 & $\begin{array}{r}13.3 \pm 1.56 \\
(12.2-14.4)\end{array}$ & $\begin{array}{r}14.3 \pm 0.44 \\
(14.0-14.8)\end{array}$ \\
\hline BBP & $\begin{array}{r}2.7 \pm 0.29 \\
(2.3-3.1) \\
\end{array}$ & 2.8 & $2.8 \pm 0.00$ & $\begin{array}{r}3.0 \pm 0.31 \\
(2.7-3.3) \\
\end{array}$ \\
\hline BMF & $\begin{array}{r}3.1 \pm 0.17 \\
(3.0-3.4)\end{array}$ & 3.5 & $\begin{array}{r}3.3 \pm 0.07 \\
(3.2-3.3)\end{array}$ & $3.0 \pm 0.00$ \\
\hline LIF & $\begin{array}{r}7.6 \pm 0.31 \\
(7.1-7.9)\end{array}$ & 8.5 & $\begin{array}{r}7.4 \pm 0.71 \\
(6.9-7.9)\end{array}$ & $\begin{array}{r}8.9 \pm 0.47 \\
(8.4-9.3)\end{array}$ \\
\hline BIF & $\begin{array}{r}3.1 \pm 0.16 \\
(2.9-3.3) \\
\end{array}$ & 3.2 & $\begin{array}{r}3.2 \pm 0.49 \\
(2.8-3.5) \\
\end{array}$ & $\begin{array}{r}3.1 \pm 0.07 \\
(3.0-3.3) \\
\end{array}$ \\
\hline LB & $\begin{array}{r}8.3 \pm 0.39 \\
(7.9-8.7)\end{array}$ & 8.1 & $\begin{array}{r}7.8 \pm 0.07 \\
(7.7-7.8)\end{array}$ & $\begin{array}{r}8.9 \pm 0.21 \\
(8.7-9.1)\end{array}$ \\
\hline CLM1-3 & $\begin{array}{r}11.8 \pm 0.34 \\
(11.3-12.2)\end{array}$ & 10.5 & $\begin{array}{r}11.1 \pm 0.42 \\
(10.8-11.4)\end{array}$ & $\begin{array}{r}11.5 \pm 0.56 \\
(11.0-12.1)\end{array}$ \\
\hline BM1 & $\begin{array}{r}3.5 \pm 0.23 \\
(3.3-3.8)\end{array}$ & 3.2 & $\begin{array}{r}3.5 \pm 0.35 \\
(3.2-3.7)\end{array}$ & $\begin{array}{r}3.4 \pm 0.23 \\
(3.3-3.7) \\
\end{array}$ \\
\hline
\end{tabular}

Notes: Measurements are in millimetres. Mean \pm 1 SD and observed range (in parentheses) are listed. Specimens measured are indicated below.

Northeast-Gunung Masarang: BMNH 97.1.2.20. Tomohon: NMB 3327, 4759. Amurang: BMNH 21.2.9.4; MZB 5810.

Northcentral - AMNH 153011.

Core - Tomado: AMNH 224317. Gimpu: USNM 219712 (holotype of Lenomys longicaudus).

Southwest Peninsula - Gunung Lompobatang: AMNH 101125, 101126, 101128 (holotype of Lenomys meyeri lampo).

Source: Author's data. 
2. Characterisation of the endemic Sulawesi Lenomys meyeri (Muridae, Murinae)

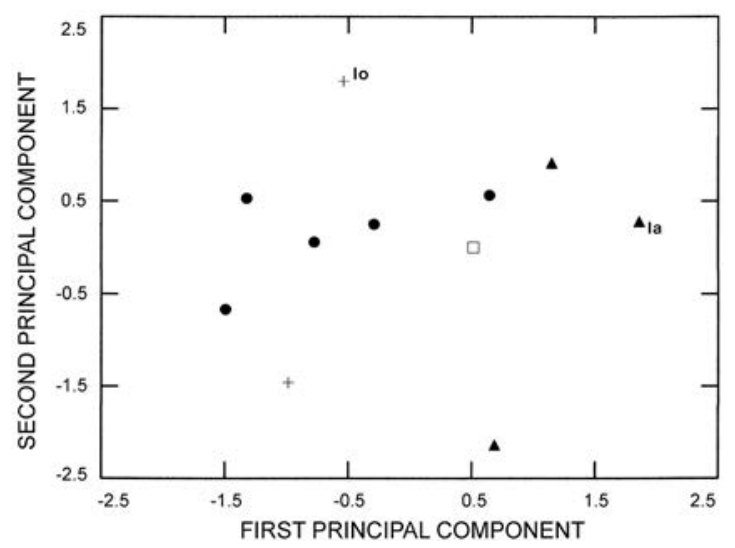

Figure 2.10: Specimen scores representing modern examples of Lenomys meyeri projected on first and second principal components extracted from principalcomponents analysis of 16 cranial and two dental log-transformed variables. Symbols: filled circle $=$ northern peninsula east of Gorontalo region $(N=5$; Amurang, Gunung Masarang, Tomohon); empty square = Bumbulan, west of Gorontalo region $(N=1)$; cross $=$ central region $(N=2$; Gimpu, Tomado); filled triangle $=$ southwest peninsula ( $N=3$; Gunung Lompobatang). Abbreviations identify scores for holotypes: la = Lenomys meyeri lampo; lo = Lenomys longicaudus. See Table 2.4 for correlations of variables and percent variance.

Source: Author's data.

Table 2.4: Results of principal-components analysis comparing modern specimens of Lenomys meyeri.

\begin{tabular}{|l|r|r|}
\hline \multicolumn{1}{|c|}{ Variable } & \multicolumn{2}{|c|}{ Correlations } \\
\hline & PC1 & PC2 \\
\hline ONL & $0.70(\mathrm{C})$ & 0.23 \\
\hline ZB & $0.71(\mathrm{C})$ & 0.40 \\
\hline IB & -0.43 & 0.35 \\
\hline LR & 0.45 & -0.08 \\
\hline BR & -0.26 & 0.09 \\
\hline BBC & -0.14 & 0.21 \\
\hline HBC & 0.19 & 0.23 \\
\hline BZP & $0.62(\mathrm{C})$ & -0.40 \\
\hline LD & $0.88(\mathrm{~A})$ & -0.03 \\
\hline PPL & -0.11 & $-0.66(\mathrm{C})$ \\
\hline LBP & 0.56 & 0.43 \\
\hline BBP & $0.76(\mathrm{~B})$ & 0.40 \\
\hline BMF & -0.43 & 0.22 \\
\hline LIF & $0.82(\mathrm{~B})$ & -0.52 \\
\hline BIF & -0.23 & $-0.85(\mathrm{~A})$ \\
\hline LB & $0.64(\mathrm{C})$ & -0.19 \\
\hline CLM1-3 & -0.16 & -0.43 \\
\hline BM1 & -0.44 & $-0.63(\mathrm{C})$ \\
\hline Eigenvalue & 0.022 & 0.012 \\
\hline \% Variance & 38.4 & 19.9 \\
\hline
\end{tabular}

Notes: Correlations (loadings) of log-transformed values for 16 cranial and 2 dental variables are based on 11 specimens; see Figure 2.10.

(A) $\mathrm{P} \leq 0.001$; (B) $\mathrm{P} \leq 0.01$; (C )P $\leq 0.05$. 
The specimen from Gimpu is the holotype of L. longicaudus, which Miller and Hollister (1921: 95) thought was distinctive because its tail is longer than length of head and body, but they had no comparative material at hand, and among the specimens I examined tail length ranges from slightly shorter to slightly longer than length of head and body (Table 2.1). The dental traits they highlighted in their diagnosis are not diagnostic and fall within the range of variation seen in larger samples of L. meyeri.

\section{Ecological notes}

Observations provided here come from my capture of a young adult male from Tomado (AMNH 224317) and an adult female from Sungai Sadaunta (AMNH 226813) in lowland tropical evergreen rainforest (see Table 2.5 for details).

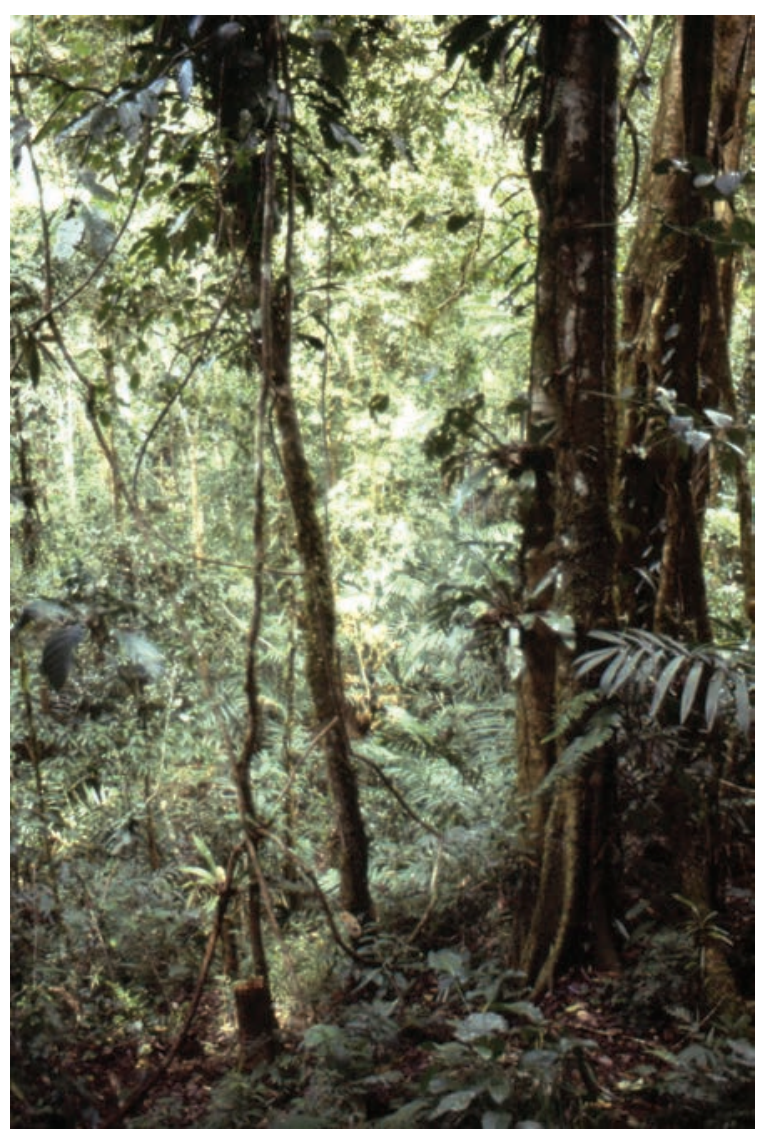

Figure 2.11: Hillside primary forest along Sungai Sadaunta in area near where Lenomys meyeri was caught. Photographed in 1976.

Source: Photograph by Author. 


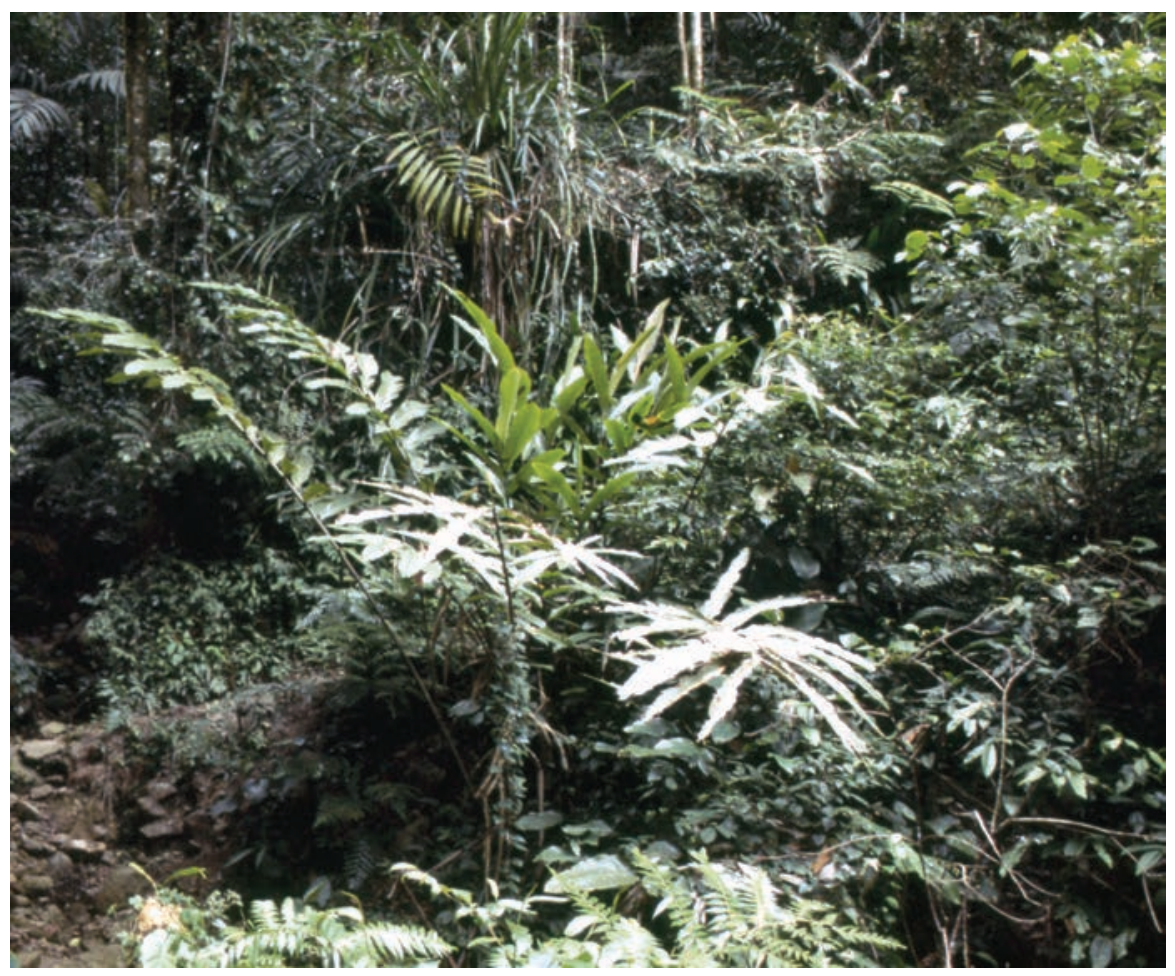

Figure 2.12: Ground cover over terrace where burrow of Lenomys meyeri was located. Burrow system was in a stable area near edge of a gently sloping terrace above and back from a stream. Dry leaves and broken branches covered the ground beneath a moderately dense undergrowth of shrubs, palm and tree seedlings, ferns, and gingers. Surrounding forest was tall second-growth regenerating over clearing made by a fallen canopy tree. Primary forest covered slopes back of this disturbed area; see Table 2.5. Photographed in 1976.

Source: Photograph by Author.

Most ecological information comes from the rat collected on Sungai Sadaunta, which I kept captive for about a month. It eagerly accepted and consumed katydids, grasshoppers, and moths (usually eating everything except legs and wings); large and small fruit from several species of figs (Ficus spp.); small and young tender green plants, tips of fern fronds, palm heart (mostly the thin embryonic leaves); and bait (peanut butter, raisins, oatmeal, and bacon ground into a mash). Tougher leaves of sapling or understorey trees were rejected as were several other kinds of non-fig fruits. It also required a constant source of drinking water. 
Table 2.5: Summary of microhabitats at trapping sites and other relevant information for two specimens of Lenomys meyeri collected in Central Sulawesi, 1974-1975.

\begin{tabular}{|c|c|c|c|}
\hline $\begin{array}{l}\text { Locality, AMNH } \\
\text { and (ASE-field) } \\
\text { numbers }\end{array}$ & $\begin{array}{l}\text { Elevation } \\
\text { (m) }\end{array}$ & Date & Trap site and other information \\
\hline $\begin{array}{l}\text { Tomado } 224317 \\
\text { (1612) }\end{array}$ & 1000 & $\begin{array}{l}\text { May } \\
1974\end{array}$ & $\begin{array}{l}\text { Caught during the night on decaying, moss and } \\
\text { vine-covered trunk bridging narrow stream about } \\
2 \mathrm{~m} \text { above water level. On one bank of stream is } \\
\text { tall primary forest that has been slightly disturbed } \\
\text { by removal of a tree for lumber, some rattan and } \\
\text { occasionally a sugar palm. The opposite bank is } \\
\text { scrubby, consisting of a few coffee trees next to } \\
\text { scrub and low second-growth forest, which abuts a } \\
\text { grassy meadow; ground cover here is mostly grass, } \\
\text { shrubs, and ferns. Minimum and maximum ambient } \\
\left.\text { temperatures ( }{ }^{\circ} \mathrm{F}\right) \text { during a } 30 \text {-day period were } 65.0 \\
(56-67) \text { and } 80.9 \text { (70-94), respectively. }\end{array}$ \\
\hline $\begin{array}{l}\text { Sungai } \\
\text { Sadaunta } \\
226813 \text { (4401a) }\end{array}$ & 915 & $\begin{array}{l}\text { April } \\
1976\end{array}$ & $\begin{array}{l}\text { Dug out of burrow near edge of a gently sloping } \\
\text { terrace about } 1.5 \text { m above a stream and } 2.5 \mathrm{~m} \\
\text { back from it. The area was stable, the soil firmly } \\
\text { held in place by roots, and the ground covered with } \\
\text { dry leaves and litter from rotting small branches } \\
\text { and rattan. Undergrowth was knee-to-waist high } \\
\text { consisting of shrubs, palm and tree seedlings, } \\
\text { ferns, gingers, and rattan rosettes. Forest shading } \\
\text { this spot was tall second-growth festooned with } \\
\text { woody vines in the understorey and represented } \\
\text { regenerating growth over an area where a large } \\
\text { canopy tree fell, marked now only by the decaying } \\
\text { base of its trunk on the terrace edge near the } \\
\text { burrow and the remainder of the trunk lying on } \\
\text { the terrace partially covered by undergrowth. Tall } \\
\text { primary forest surrounded this disturbed spot. } \\
\text { Minimum and maximum ambient temperatures ( }{ }^{\circ} \mathrm{F} \text { ) } \\
\text { during a } 4 \text {-month period was } 66.9 \text { ( } 62-70 \text { ) and } \\
75.2 \text { (70-86), respectively. See the habitat images } \\
\text { in Figures } 2.11 \text { and } 2.12 \text {. }\end{array}$ \\
\hline
\end{tabular}

Notes: Descriptions of the trapping sites are summarised from my field journals (in Mammalogy archives at AMNH). ASE designates Archbold Sulawesi Expedition field numbers. Both sites were in lowland tropical evergreen rainforest (as defined by Whitmore, 1984).

Source: Author's data.

Both the Tomado and Sadaunta rats consumed their own faeces (coprophagous), either picking the pellets from the cage floor or taking them directly from the anus.

The Sadaunta animal gave birth to one young: the pup began uncoordinated movements and ears opened on day 17, pup actively wandered around cage and climbed on supports by day 21 at which time the eyes opened and although still nursing the pup nibbled on bait and palm heart. 
The Tomado and Sadaunta animals slept in a leaf nest during the day and were active only at night. They could also move along branches; their short and wide feet with huge fleshy pads and curved claws are fit for climbing - this species nests in ground burrows and likely forages during the night on substrates above ground in the understorey.

A diagram of the burrow and other details are provided in Figure 2.13. During the night the burrow entrance was open but in the morning had been sealed by a plug of dry leaves.

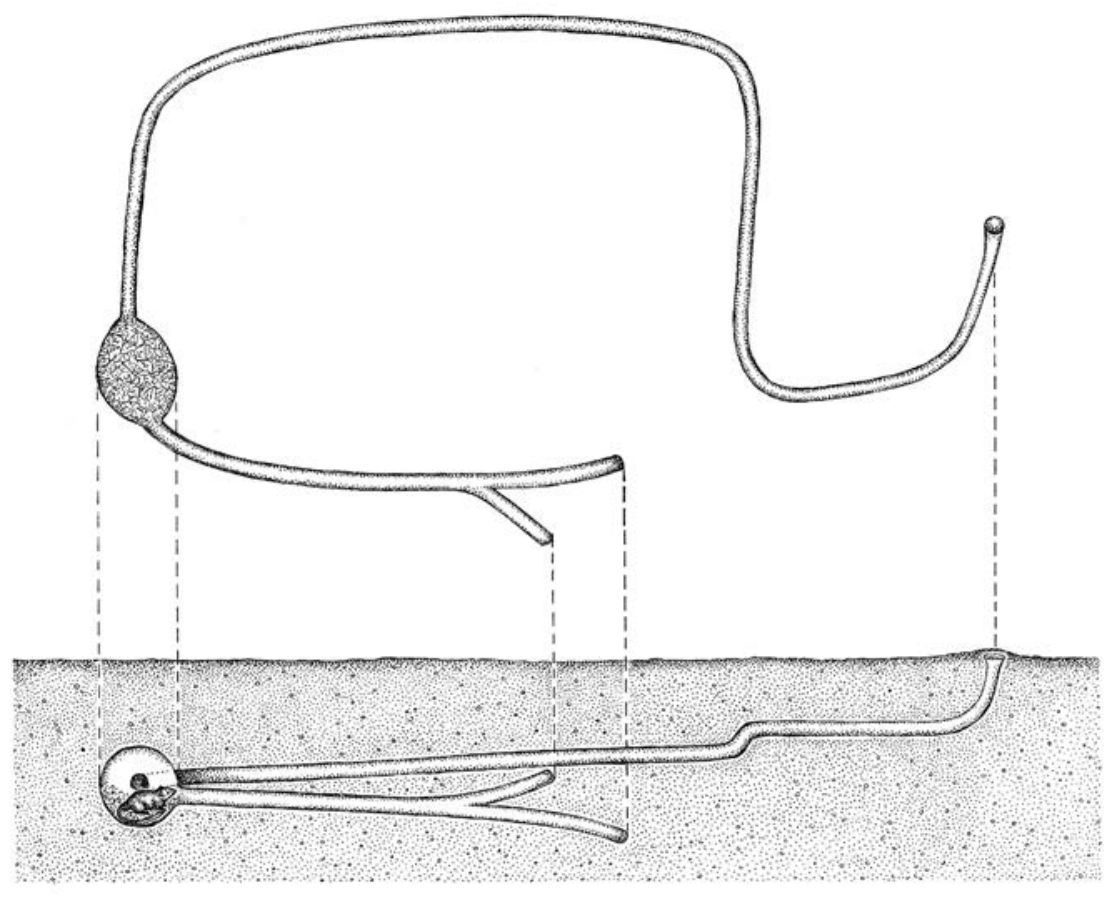

Figure 2.13: Burrow system of Lenomys meyeri excavated on a stream terrace adjacent to Sungai Sadaunta, 915 m (3 April 1976). Tunnel system was $5.6 \mathrm{~m}$ long $(90 \mathrm{~cm}$ at its widest and $248 \mathrm{~cm}$ at its longest, tunnels were $7-10 \mathrm{~cm}$ in diameter) with a single entrance and two blind passages; entire structure lay about $45 \mathrm{~cm}$ below ground surface. The oval chamber was $30 \mathrm{~cm}$ long and $20 \mathrm{~cm}$ in diameter and partially filled with compacted dry leaves forming a shallow bowl-shaped nest. An adult female (AMNH 226813) was found in the burrow.

Source: Drawing by Patricia Wynne. 
Taxonomic Tapestries

\section{Subfossils}

Subfossil specimens of L. meyeri are identified and documented in Table 2.6.

Table 2.6: Subfossil fragments of Lenomys meyeri from the southwest peninsula of Sulawesi.

\begin{tabular}{|c|c|c|}
\hline Cave and specimen & Age & Description \\
\hline \multicolumn{3}{|l|}{ BATU EJAJA } \\
\hline Specimen 1 & adult & Most of left dentary, molar row intact, incisor missing. \\
\hline AMNH 272963 & adult & Small fragment of right pelvic girdle. \\
\hline \multicolumn{3}{|l|}{ BATU EJAJA 2} \\
\hline AMNH 265029 & adult & Fragment of left dentary containing $\mathrm{m} 2$ and portion of incisor. \\
\hline AMNH 265030 & adult & Incomplete right upper incisor. \\
\hline AMNH 265031 & adult & Distal tip of right upper incisor. \\
\hline Specimen 2 & adult & Most of right dentary, molar row intact, incisor missing. \\
\hline Specimen 3 & adult & Piece of right dentary, $\mathrm{m} 1$ and $\mathrm{m} 2$ present, incisor intact. \\
\hline Specimen 4 & adult & Fragment of right dentary, basal piece of incisor, no molars. \\
\hline Specimen 5 & adult & Piece of left dentary, $\mathrm{m} 1$ and $\mathrm{m} 2$ present, incisor intact. \\
\hline Specimen 6 & adult & Fragment of left dentary, molar row intact, incisor missing. \\
\hline Specimen 7 & adult & Fragment of left dentary, molar row intact, incisor missing. \\
\hline Specimen 8 & adult & Piece of right dentary, $\mathrm{m} 1$ and $\mathrm{m} 2$ present, incisor intact. \\
\hline Specimen 9 & adult & Fragment of right dentary, $\mathrm{m} 1$ and basal half of incisor present. \\
\hline Specimen 10 & adult & Piece of left dentary, all molars present, basal piece of incisor. \\
\hline \multicolumn{3}{|l|}{ LEANG BURUNG 1} \\
\hline AMNH 265022-A & adult & Most of left dentary, molar row and incisor intact (Figure 2.14). \\
\hline AMNH 265023-A & adult & Anterior fragment of left dentary, molars and incisor missing. \\
\hline AMNH 265028-B & young & Fragment of left dentary, most of incisor present, molars gone. \\
\hline AMNH 265024-B & adult & Most of right lower incisor. \\
\hline AMNH 265025-A & adult & Distal piece of right upper incisor. \\
\hline AMNH 265026-A & adult & Distal fragment of right upper incisor. \\
\hline AMNH 265027-A & adult & Nearly complete left pelvic girdle. \\
\hline AMNH 272961 & adult & Intact left femur. \\
\hline AMNH 272962 & adult & Distal portion of right tibia. \\
\hline
\end{tabular}

Note: Identities of Specimens 1-10 from Batu Ejaja 2 were discussed more fully elsewhere (Musser, 1984).

Source: Author's data. 


\section{Lenomys grovesi, new species}

\section{Holotype and type locality}

The holotype and only example of the species is AMNH 265021, a subfossil right dentary from an adult collected on 26 July 1969 by members of the AustralianIndonesian Archaeological Expedition to Sulawesi under the leadership of DJ Mulvaney and RP Soejono. The dentary is mostly undamaged except for the missing tip of the coronoid process; all molars are intact; root of the incisor is embedded within the dentary, the rest of the incisor is missing (Figures 2.14 and 2.15). Dental measurements are listed in Table 2.7 .

The type locality is Leang Burung 1, a cave near the village of Pakalu, 'about $2 \mathrm{~km}$ north of the main road from Maros, $10 \mathrm{~km}$ to the west' (Mulvaney and Soejono, 1970: 169 and map on p. 170; the site is also mapped by Bulbeck [2004: 130]), less than $100 \mathrm{~m}$ (locality 12 in Figure 2.2a), in the southeastern portion of the southwestern peninsula, Propinsi Sulawesi Tengah, Indonesia.

Mulvaney and Soejono (1970) identified the cave as 'Leang Burung' but it has been designated 'Leang Burung $1^{\prime}$ in subsequent literature to distinguish it from the nearby 'Leang Burung 2' (Glover, 1981; Bulbeck, 2004). The subfossil was excavated from 'Trench A'. Mulvaney and Soejono (1970: 170) wrote that

Most of Trench A cut through recent limestone rubble that reached to bedrock. Just inside the line of overhang, however, bedrock dipped vertically, and excavation showed that beneath the rubble lay a zone of disturbed occupation material, and underneath, undisturbed deposit. The depth reached in our test trench was $4 \mathrm{~m}$, at which depth excavation became impossible because of massive fallen rocks.

Mulvaney and Soejono (1970: 171) indicated that charcoal from a depth of about $270 \mathrm{~cm}$ in Trench A was dated at $2820 \pm 210(2,360-3,460)$ years BP, and D. Bulbeck (in a letter to me, 1997; 2004: 136) indicated that 3,000-2,000 years BP are the outside limits for Trench A; the time frame is late Holocene. 
Taxonomic Tapestries

Table 2.7: Measurements of mandibular molars from subfossil and modern samples of Lenomys meyeri and the subfossil specimen of Lenomys grovesi.

\begin{tabular}{|c|c|c|c|c|c|}
\hline $\begin{array}{l}\text { Species, } \\
\text { locality and specimen }\end{array}$ & clm1-3 & alm1-3 & bm1 & bm2 & bm3 \\
\hline \multicolumn{6}{|l|}{ L. meyeri } \\
\hline \multicolumn{6}{|l|}{ SUBFOSSIL } \\
\hline \multicolumn{6}{|l|}{ Southwest Peninsula } \\
\hline \multicolumn{6}{|l|}{ Leang Burung 1} \\
\hline AMNH 265022 & 11.5 & 11.9 & 3.0 & 3.1 & 2.7 \\
\hline \multicolumn{6}{|l|}{ Batu Ejaja } \\
\hline AMNH 265029 & - & - & - & 3.1 & -Batu Ejaja \\
\hline \multicolumn{6}{|l|}{$\begin{array}{l}\text {-Batu Ejaja } \\
\text { Panganreang Tudea }\end{array}$} \\
\hline $\begin{array}{l}\text { Specimens 1-10 } \\
\text { (Musser, 1984: 69) }\end{array}$ & $\begin{array}{r}11.2 \pm 0.47 \\
(10.7-11.9) 5\end{array}$ & $\begin{array}{r}11.7 \pm 0.82 \\
(10.9-13.1) 8 \\
\end{array}$ & $\begin{array}{l}3.1 \pm 0.11 \\
(3.0-3.3) 8\end{array}$ & $\begin{array}{l}3.1 \pm 0.08 \\
(3.0-3.2) 8\end{array}$ & $\begin{array}{l}2.8 \pm 0.14 \\
(2.6-2.9) 5\end{array}$ \\
\hline \multicolumn{6}{|l|}{ MODERN } \\
\hline Northeast & $\begin{array}{r}11.2 \pm 0.34 \\
(10.7-11.6) 7\end{array}$ & $\begin{array}{r}11.6 \pm 0.51 \\
(10.9-12.2) 5\end{array}$ & $\begin{array}{l}3.2 \pm 0.17 \\
(3.0-3.4) 7\end{array}$ & $\begin{array}{l}3.2 \pm 0.22 \\
(2.9-3.5) 7\end{array}$ & $\begin{array}{l}2.8 \pm 0.16 \\
(2.6-3.0) 7\end{array}$ \\
\hline Northcentral & 10.0 & 9.9 & 2.9 & 2.9 & 2.7 \\
\hline \multicolumn{6}{|l|}{ Core } \\
\hline AMNH 224317 & 11.0 & 11.4 & 3.3 & 3.3 & 3.0 \\
\hline USNM 219712 & 10.4 & 10.5 & 3.0 & 3.1 & 2.7 \\
\hline Southwest Peninsula & $\begin{array}{r}10.7 \pm 0.38 \\
(10.3-11.2) 5 \\
\end{array}$ & \begin{tabular}{|r|}
$11.3 \pm 0.43$ \\
$(10.7-11.8) 5$ \\
\end{tabular} & $\begin{array}{l}3.1 \pm 0.18 \\
(2.9-3.3) 5\end{array}$ & \begin{tabular}{|l|}
$3.1 \pm 0.16$ \\
$(2.9-3.3) 5$ \\
\end{tabular} & $\begin{array}{l}2.8 \pm 0.16 \\
(2.6-3.0) 5 \\
\end{array}$ \\
\hline \multicolumn{6}{|l|}{ Lenomys grovesi } \\
\hline \multicolumn{6}{|l|}{ SUBFOSSIL } \\
\hline \multicolumn{6}{|l|}{ Southwest Peninsula } \\
\hline \multicolumn{6}{|l|}{ Leang Burung I } \\
\hline AMNH 265021 & 9.3 & 9.6 & 2.7 & 2.6 & 2.3 \\
\hline
\end{tabular}

Notes: Measurements are in millimeters. Mean $\pm 1 \mathrm{SD}$, observed range (in parentheses), and size of sample is listed. Modern specimens measured are identified below:

Northeast - Gunung Masarang: BMNH 97.1.2.20. Tomohon: NMB 3326, 3327, 4759. Langoon: RMNH 18302, holotype of Mus meyeri. Amurang: (BMNH 21.2.9.4). 'Minahassa': RMNH 21233.

Northcentral-Bumbulan: AMNH 153011.

Core - Tomado and Gimpu (holotype of Lenomys longicaudus).

Southwest peninsula - Gunung Lompobatang: AMNH 101124-28 (includes holotype of Lenomys meyeri lampo).

Source: Author's data. 


\section{Diagnosis}

In morphology of the dentary and molars, and the occlusal patterns formed by molar cusps, Lenomys grovesi is a diminutive version of the larger-bodied L. meyeri, with the added distinction that $\mathrm{m} 3$ is relatively narrower as contrasted with the dental proportions in L. meyeri.

\section{Etymology}

The patronym honours Colin Groves, a professional colleague and friend who over the years has consistently impressed me with his unique intellect and the breadth of his scholarship - his impact on the study of mammalian diversity will influence the nature of research long after the rest of us disappear into that place where the winds begin and the sky reflects infinity.

\section{Geographic distribution and habitat}

Leang Burung 1 is located on the western coastal plain at about $100 \mathrm{~m}$ in the Maros karst region at the southern end of the southwestern peninsula of Sulawesi (see the map in Simons and Bulbeck, 2004: 168). Forest cover on the coastal plain during middle and late Holocene times likely consisted of tropical lowland evergreen or semi-evergreen rainforest formations. Based upon analyses of the vertebrate faunal composition excavated from caves and rock shelters, Simons and Bulbeck (2004: 178) speculate that the environment in this region '... consisted of a mosaic of copses of primary forest, expanses of secondary forest, and possibly more open habitats between about 7000 and 2000 BP.' I strongly suspect $L$. grovesi to be restricted to forested terrain; the mosaic landscape suggested by Simons and Bulbeck would support populations of L. grovesi and the other murids represented by subfossils excavated at Leang Burung 1 (Table 2.8), and from other caves in the Maros region (Table 2.9). During my trapping in the central part of Sulawesi, I found Lenomys meyeri, Paruromys dominator, Maxomys hellwaldii, and Rattus hoffmanni, which are represented by subfossils from Leang Burung 1 (Table 2.8), to inhabit primary forest or secondary growth that had nearly assumed the structure of old-growth formations. 
Taxonomic Tapestries

Table 2.8: Subfossil representatives of murids excavated from Leang Burung 1.

\begin{tabular}{|c|c|c|}
\hline Species & $\begin{array}{l}\text { Trench A } \\
(2820 \pm 210 \mathrm{BP})\end{array}$ & $\begin{array}{l}\text { Trench B } \\
(3420 \pm 400 \mathrm{BP})\end{array}$ \\
\hline Lenomys grovesi & AMNH 265021 & \\
\hline Lenomys meyeri & $\begin{array}{r}\text { AMNH } 265022 \\
265023,265025- \\
265027\end{array}$ & AMNH 265024,265028 \\
\hline Paruromys dominator & $\begin{array}{r}\text { AMNH } 265002- \\
265004\end{array}$ & $\begin{array}{r}\text { AMNH } 265005,265006, \\
269960,269962\end{array}$ \\
\hline Maxomys hellwaldii & - & AMNH 265016 \\
\hline Rattus bontanus & AMNH 265032 & AMNH 269957 \\
\hline Rattus hoffmanni & AMNH 265032 & - \\
\hline Rattus tanizumi & - & AMNH 265040 \\
\hline
\end{tabular}

Notes: Radiocarbon dates are from Mulvaney and Soejono (1970); also see Figure 2 in Bulbeck (2004: 133).

Of the seven species listed, all are endemic to Sulawesi except for Rattus tanizumi, which is a member of the geographically broadly distributed Rattus rattus complex (Aplin et al., 2011), and represents an unintended anthropogenic introduction to the endemic Sulawesi murid fauna.

Results from analysis of external traits and morphometric data from skull and dental measurements in population samples (Musser, unpublished data) coupled with analyses of DNA sequences (Achmadi et al., 2013) indicate that Maxomys hellwaldii as listed here will likely prove to be a complex of species, reminiscent of the diversity uncovered in populations of Maxomys surifer and M. whiteheadi from mainland Indochina and islands on the Sunda Shelf, each previously considered as a single species (Gorog et al., 2004).

Source: Author's data.

Whether L. grovesi is extinct or still occurs on the southwestern peninsula is unknown. Most of the lowland forest was long ago removed and the region converted to agriculture (Fraser and Henson, 1996; Whitten et al., 1987), which comprises much of the present landscape south of the Tempe Depression (see map 8d in Mackinnon, 1997); however, remnant tracts of lowland forest are present, especially in karst areas (Whitten et al., 1987: 102; Froehlich and Supriatna, 1996). Unfortunately, these patches have never been adequately, if it all, surveyed for endemic species of murids. Most samples of modern specimens come from the flanks of the volcano Gunung Lompobatang in either montane or mid elevational forests, which have yielded Lenomys meyeri, Paruromys dominator, Maxomys hellwaldii and M. musschenbroekii, Rattus hoffmanni and $R$ bontanus, but not L. grovesi (Musser, ms). 
Table 2.9: Murid species represented by middle and late Holocene subfossils excavated from caves and rock shelters on the southern end of the southwestern peninsula of Sulawesi.

\begin{tabular}{|l|l|l|l|l|l|l|l|l|}
\hline Species & $\begin{array}{l}\text { Batu } \\
\text { Ejaja }\end{array}$ & $\begin{array}{l}\text { Bola } \\
\text { Batu }\end{array}$ & $\begin{array}{l}\text { Panganreang } \\
\text { Tudea }\end{array}$ & $\begin{array}{l}\text { Panisi } \\
\text { Ta'batu }\end{array}$ & $\begin{array}{l}\text { Leang } \\
\text { Burung 1 }\end{array}$ & $\begin{array}{l}\text { Ulu } \\
\text { Leang 1 }\end{array}$ & PattaE & $\begin{array}{l}\text { Leang } \\
\text { Karassa }\end{array}$ \\
\hline Lenomys grovesi & & & & & + & & & \\
\hline Lenomys meyeri & + & + & + & & + & & & \\
\hline Paruromys dominator & + & + & + & & + & + & & + \\
\hline Taeromys celebensis & & & + & & & & & \\
\hline Taeromys punicans & + & + & & & & & + & \\
\hline Maxomys hellwaldii & + & & & & + & & & \\
\hline $\begin{array}{l}\text { Maxomys } \\
\text { musschenbroekii }\end{array}$ & & + & & & & & & \\
\hline $\begin{array}{l}\text { Bunomys } \\
\text { chrysocomus }\end{array}$ & & & & & & + & & \\
\hline Bunomys andrewsi & + & & & & & + & & \\
\hline Rattus bontanus & + & + & + & + & + & + & & + \\
\hline Rattus hoffmanni & + & & & & + & & & \\
\hline Rattus tanezumi & & & & + & + & + & & \\
\hline
\end{tabular}

Notes: The sites are mapped and described in Mulvaney and Soejono (1970), Bulbeck (2004), and Simons and Bulbeck (2004).

My identifications of the samples are documented in Musser (1984, in press), Simons and Bulbeck (2004), and in unpublished manuscripts either being prepared by me or submitted for publication. Some of the names in the table differ from those recorded in the publications. The specimens of Bunomys andrewsi were originally identified by me as $B$. heinrichi (listed in tables by Simons and Bulbeck, 2004), which is the name available for the population of $B$. andrewsi occurring on the southwestern peninsula. The Rattus bontanus have been documented as either $R$. xanthurus foramineus (Musser, 1984) or $R$. foramineus (Simons and Bulbeck, 2004), but foramineus is a synonym of $R$. bontanus, a southwestern peninsular endemic (Musser and Carleton, ms). Examples determined as Rattus tanezumi have either been referred to as $R$. rattus (Musser, 1984) or R. tanezumi (Simons and Bulbeck, 2004); see note to Table 2.8.

Results from analysis of external traits and morphometric data from skull and dental measurements in population samples (Musser, unpublished data) coupled with analyses of DNA sequences (Achmadi et al., 2013) indicate that Maxomys hellwaldii and M. musschenbroekii as listed here will likely prove to be a complex of species, reminiscent of the diversity uncovered in populations of Maxomys surifer and M. whiteheadi from mainland Indochina and islands on the Sunda Shelf, each previously considered as one species (Gorog et al., 2004).

Source: Author's data. 

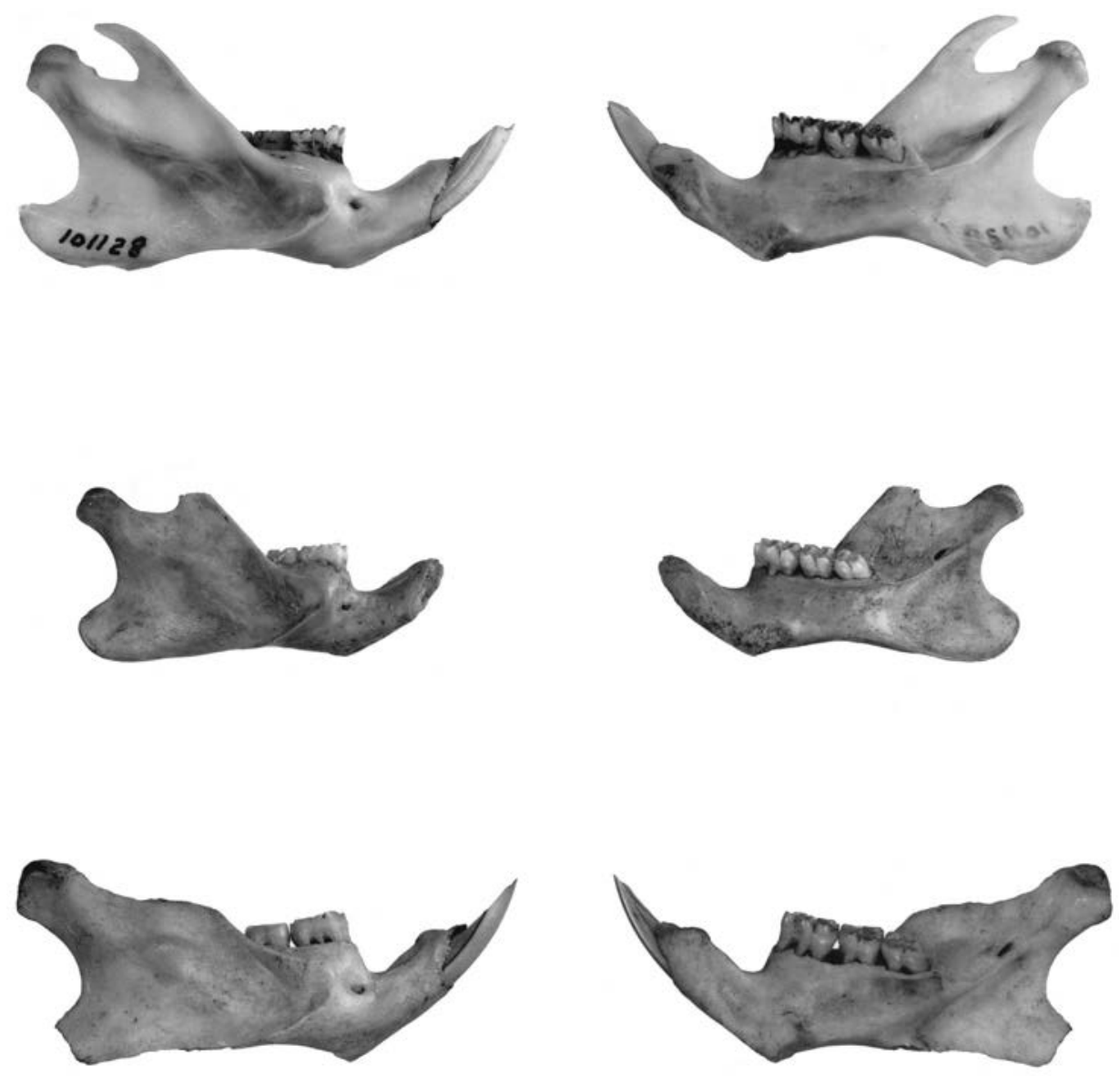

Figure 2.14: Dentaries from Lenomys obtained in the southwest peninsula. Upper row: right dentary of modern Lenomys meyeri (AMNH 101128, holotype of $L$. $m$. lampo) from Gunung Lompobatang, 2,200 m. Middle row: right dentary of subfossil $L$. grovesi (AMNH 265021) from Leang Burung 1 on coastal plain. Lower row: left dentary (image was flipped for comparison with the two other specimens) of subfossil L. meyeri (AMNH 265022) from Leang Burung 1. X2.

Source: Photograph by Peter Goldberg. 

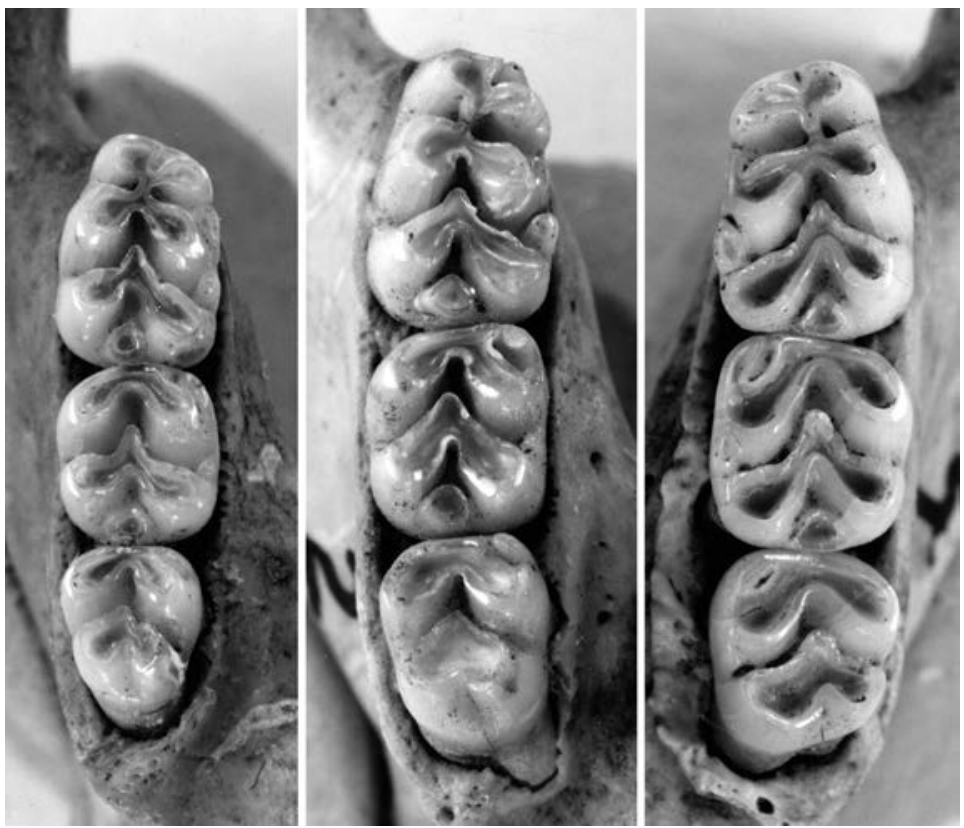

Figure 2.15: Occlusal views of subfossil mandibular molar rows from two species of Lenomys. Left, L. grovesi (AMNH 265021; clm1-3 = $9.3 \mathrm{~mm}$; right toothrow) from Leang Burung I; Middle, L. meyeri, (Specimen 2; clm1-3 = $11.3 \mathrm{~mm}$; right toothrow) from Panganreang Tudea; Right, $L$. meyeri, (Specimen 1; clm1-3 = $10.7 \mathrm{~mm}$; left toothrow) from Batu Ejaja.

Source: Photograph by Peter Goldberg.

\section{Description and comparisons}

Lenomys grovesi is a miniature version of L. meyeri, assuming size of dentary and molars reflect overall physical size of the animals; no other examples of L. meyeri at hand, either subfossil or modern, matches the smaller dimensions characteristic of L. grovesi. Configuration of the dentary in L. grovesi conforms to that described previously for L. meyeri, but is simply much smaller (Figure 2.14). So are the molars, a difference evident visually (Figure 2.15), by measurements (Table 2.7), and quantitatively by the distribution of specimen scores for samples of $L$. grovesi and $L$. meyeri projected on first and second principal components extracted from principal-components analysis (Figure 2.16). Along the first component, covariation among all variables isolates the score for $L$. grovesi, reflecting its smaller molars and shorter toothrow, and the greater size of these dental elements in L. meyeri ( $r=0.84-0.94$; Table 2.10). Position of the score for $L$. grovesi along the second axis indicates its relatively narrower $\mathrm{m} 3(r=-0.53)$ compared with the proportion in L. meyeri. 


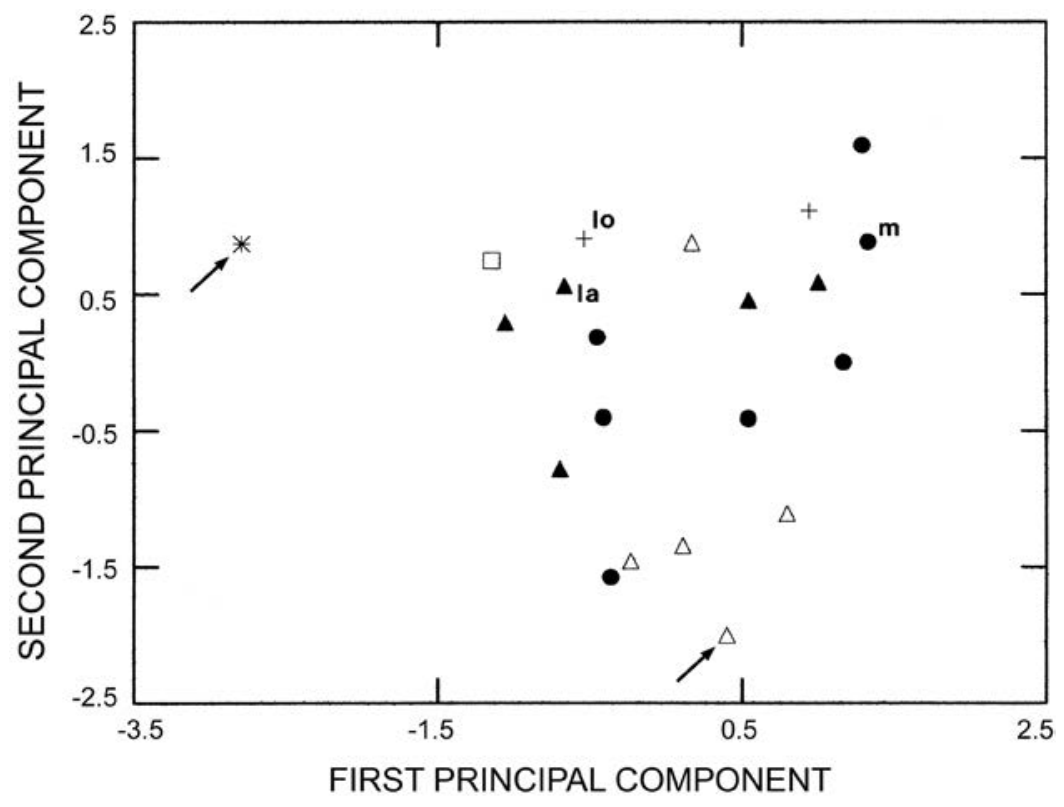

Figure 2.16: Scores representing specimens of modern and subfossil Lenomys meyeri and subfossil $L$. grovesi projected on first and second principal components extracted from principal-components analysis of four log-transformed dental variables. Symbols for Lenomys meyeri: filled circle $=$ northern peninsula east of Gorontalo region ( $N=7$; Amurang, Gunung Masarang, Tomohon, Langoon); empty square = Bumbulan, west of Gorontalo region ( $N=1)$; cross $=$ central region $(\mathbf{N}=2$;

Gimpu, Tomado); filled triangle = southwest peninsula ( $N=5$; Gunung Lompobatang); open triangle = southwest peninsula $(\mathrm{N}=5$; subfossils from Batu Ejaja, Panganreang Tudea, and Leang Burung 1). Symbol for L. grovesi: asterisk = southwest peninsula ( $\mathbf{N}=1$; Leang Burung 1 ). Abbreviations identify scores for holotypes: la = Lenomys meyeri lampo; lo = Lenomys longicaudus; $\mathrm{m}=$ Mus meyeri. Arrows point to scores for subfossils from Leang Burung 1, the holotype of L. grovesi (asterisk) and AMNH 265022 representing $L$. meyeri (empty triangle). See Table 2.10 for correlations of variables and per cent variance. 
Table 2.10: Results of principal-components analysis comparing modern and subfossil samples of Lenomys meyeri with the subfossil specimen of Lenomys grovesi.

\begin{tabular}{|l|r|r|}
\hline \multicolumn{1}{|c|}{ Variable } & \multicolumn{2}{|c|}{ Correlations } \\
\hline & PC 1 & \multicolumn{1}{|c|}{ PC 2 } \\
\hline $\mathrm{clm} 1-3$ & $0.94^{(\mathrm{A})}$ & 0.19 \\
\hline $\mathrm{bm} 1$ & $0.94^{(\mathrm{A})}$ & 0.23 \\
\hline $\mathrm{bm} 2$ & $0.94^{(\mathrm{A})}$ & 0.02 \\
\hline $\mathrm{bm} 3$ & $0.84^{(\mathrm{A})}$ & $-0.53^{(\mathrm{B})}$ \\
\hline Eigenvalue & 0.013 & 0.001 \\
\hline \% Variance & 83.8 & 8.8 \\
\hline
\end{tabular}

Note: (A) P $\leq 0.001$; (B) $\mathrm{P} \leq 0.01$. Correlations (loadings) of four dental log-transformed variables are based on 21 specimens; see Figure 2.16 .

Source: Author's data.

Except for size, other traits are shared by the two species. In both, $\mathrm{ml}$ is typically anchored by five roots, $\mathrm{m} 2$ by four, and $\mathrm{m} 3$ by three. Occlusal patterns formed by molar cusps are closely similar in both (Figure 2.15): major cusps are large and sharply defined; the anteroconid and cusp row behind it are joined by a mid-sagittal ridge; an anterocentral cusp is absent in L. grovesi, but is either present or absent in samples of $L$. meyeri; anterior and posterior labial cusplets adorn $\mathrm{ml}$, an anterolabial cusp is on $\mathrm{m} 2$ and $\mathrm{m} 3$, and a posterior labial cusplet sits on $\mathrm{m} 2$ but is absent from $\mathrm{m} 3$.

Three examples of L. meyeri are represented by molar and dental elements also excavated from level A in Leang Burung 1, as well as upper incisor fragments and a pelvic girdle (Table 2.8).

\section{Conclusion: Hypotheses}

\section{Lenomys meyeri}

That the samples of $L$. meyeri analysed here represent one widely geographically spread species is a hypothesis that has to be tested by analyses of more specimens from a broader coverage of Sulawesi than is now available, and the use of DNA sequences as well as qualitative anatomical and morphometric data. The most likely candidate for separation is the population inhabiting montane forest habitats on Gunung Lompobatang at the south end of the southwestern peninsula (locality 13 in Figure 2.2a). Presently, I assume the montane animals and those from the adjacent lowlands are members of the same population; 
dental measurements support this view, but thorough documentation remains elusive without intact modern specimens from the lowlands south of the Tempe Depression.

\section{Lenomys grovesi}

That the single small dentary and associated molars I designate L. grovesi represent a species and not just a genetic aberration in a population of $L$. meyeri seems a reasonable hypothesis set against the background of size variation in mandibular and dental elements documented for available samples of that larger-bodied species. It is also reasonable to postulate that L. grovesi is another murid endemic to the southwestern peninsula south of the Tempe Depression; Bunomys coelestis, Rattus mollicomulus, and Rattus bontanus are other members of that endemic group.

Future search in subfossil samples from the southwestern peninsula may undercover additional specimens of L. grovesi. Clason (1976: 66), for example, listed 65 fragments identified only as 'rodent' that were excavated from Ulu Leang I; this material bears critical reexamination.

\section{Colin Groves}

'Guy, this is Colin Groves,' explained Paul Ryan as he brought a thin, bespectacled Englishman sporting a Beatles-style haircut over to where I was standing, which happened to be next to a row of specimen cabinets extending the length of the rodent range in the Mammal Division of the National Museum of Natural History in Washington, DC. Colin and I shook hands and he expounded in his understated way on his research interests; I then countered with my reasons for rummaging through the trays of Asian rodents. That was in the late 1960s. Colin was then focusing on primates and I mistakenly pigeonholed him as a primatologist. Between then and now and through many visits with one another at museums in the United States and England, over dinners of Indian delicacies and standard British fare, and in one of my forest camps in Sulawesi, I came to understand the intellectual acuity of this man and the depth and range of Colin's interest and expertise in all mammal groups, their taxonomy, biogeography, and evolutionary history. Yes, he was deeply interested in primates, including fossil humans, but he also published on other groups, extending from monotremes and marsupials to rodents and ungulates. Perissodactyls and artiodactyls, however, were his first love. While sharing tea with John Hill at the British Museum, John reminisced about the time a young Colin Groves appeared in the Mammal Section to show him a thick manuscript revising ungulate taxonomy, asking about the next steps to publication, absolutely dumbfounding all the curators. 
And he never quit gathering data for his ungulate research. I fondly remember one of his visits to the American Museum when he merrily disappeared with his huge set of wooden calipers into the depths of the rhinoceros collection to emerge later with measurements of not just some but all the specimens - his eyes sparkled merrily.

Applying the honorary patronym to the small-bodied Lenomys endemic to Sulawesi also serves as a tribute to Colin for his numerous contributions to the science of mammalogy, for his friendship, for his glittering intelligence, and dedication to his profession. I would like to think that my contributions are much better than they would have been without Colin's influence.

\section{Acknowledgements}

My fieldwork in Sulawesi was supported by the former Celebes Fund of the American Museum of Natural History and Archbold Expeditions, Inc.; I was sponsored in Indonesia by the Lembaga Ilmu Pengetahuan Indonesia (LIPI) and the Museum Zoologicum Bogoriense (MZB), and also assisted by members of United States Navy Medical Research Unit No. 2 (NAMRU-2) in Jakarta. The drawings in Figures 2.1 , 2.2, 2.6, 2.8, and 2.13 are the work of Patricia Wynne; photographic prints of the skulls, molar rows, dentaries, and habitats were produced by Peter Goldberg. Curators and supporting staff attached to the various institutions I visited provided access to specimens and archival data. Without the assistance of artist, photographer, and museum staffs, I could not have accomplished my research goals.

\section{References}

Achmadi AS, Esselstyn JA, Rowe KC, Maryanto I, Abdullah MT. 2013. Phylogeny, diversity, and biogeography of Southeast Asian spiny rats (Maxomys). $J$ Mammal 94(6):1412-1423.

Aplin KP, Suzuki H, Chinen AA, Chesser RT, Ten Have J, Donnellan SC, Austin J, Frost A, Gonzalez JP, Herbreteau Y, Catzeflis F, Soubrier J, Fang Y-P, Robins J, Matisoo-Smith E, Bastos ADS, Maryanto I, Sinaga MH, Denys C, Van Den Bussche RA, Conroy C, Rowe K, Cooper A. 2011. Multiple geographic origins of commensalism and complex dispersal history of black rats. PLoS ONE 6(11):e26357, doi:10.1371/journal.pone.0026357. 
Taxonomic Tapestries

Breed WG, Musser GG. 1991. Sulawesi and Philippine rodents (Muridae): A survey of spermatozoa morphology and its significance for phylogenetic inference. Am Mus Novit 3003:1-15.

Bulbeck D. 2004. Divided in space, united in time: The Holocene prehistory of South Sulawesi. In: Keates SG, Pasveer JM, editors. Quaternary research in Indonesia. Mod Quat Re 18:129-166.

Carleton MD. 1980. Phylogenetic relationships in Neotomine-Peromyscine rodents (Muroidea) and a reappraisal of the dichotomy within New World Cricetinae. Miscellaneous Publications Museum of Zoology, University of Michigan 157:1-146.

Carleton MD, Musser GG. 1989. Systematic studies of oryzomyine rodents (Muridae, Sigmodontinae): A synopsis of Microryzomys. Bull Am Mus Nat Hist 191:1-83.

Clason AT. 1976. A preliminary note about the animal remains from the Leang I Cave, South Sulawesi, Indonesia. Mod Quat Re 2:53-67.

Fraser BJ, Henson SM. 1996. Survai jenis-jenis burung endemik di Gunung Lompobattang, Sulawesi Selatan [Survey of endemic bird species on Gunung Lompobattang, south Sulawesi]. Bogor: PHPA/BirdLife InternationalIndonesia Programme, Technical Memorandum No. 12.

Froehlich JW, Supriatna J. 1996. Secondary intergradation between Macaca maurus and $M$. tonkeanus in south Sulawesi, and the species status of $M$. togeanus. In: Fa JE and Lindburg DG, editors. Evolution and ecology of macaque societies, Cambridge: Cambridge University Press. pp. 43-70.

Glover IC. 1981. Leang Burung 2: An Upper Palaeolithic rock shelter in South Sulawesi, Indonesia. Mod Quat Re 6:1-38.

Gorog AJ, Sinanga MH, Engstrom MD. 2004. Vicariance or dispersal? Historical biogeography of three Sunda shelf murine rodents (Maxomys surifer, Leopoldamys sabanus and Maxomys whiteheadi). Biol J Linn Soc Lond 81:91109.

Hooijer DA. 1950. Man and other mammals from Toalian sites in Southwestern Celebes. Koninklije Nederlandsche Akademie van Wetenschappen, Verhandelingen Afdeling. Natuurkunde (Tweede Sectie) 46(2):1-164.

Jentink FA. 1879. On various species of Mus, collected by S. C. I. van Musschenbroek Esq. in Celebes. Notes of the Royal Zoological Museum of the Netherlands, Leyden 1(note 2):7-13. 
Jentink FA. 1887. Catalogue ostéologique des Mammifères. Muséum d'Histoire Naturelle des Pays-Bas, Tome 9. Leide: E.J. Brill. pp. 1-360.

Jentink FA. 1888. Catalogue systématique des Mammifères. Museum d'Histoire Naturelle des Pays-Bas, Tome 12. Leide: E.J. Brill. pp. 1-280.

Jentink FA. 1890. Mammalia from the Malay Archipelago. II. Rodentia, Insectivora, Chiroptera. In: Weber $\mathrm{M}$, editor. Zoologische Ergebnisse einer Reise in Niederländisch Ost-Indien. Leiden: E.J. Brill. Erster Band. pp. 115130, pls VIII-XI.

MacKinnon J, editor. 1997. Protected areas systems review of the Indo-Malayan Realm (prepared on behalf of the World Bank by the Asian Bureau for Conservation in collaboration with the World Conservation Monitoring Centre). Canterbury: Asian Bureau for Conservation Limited.

Maryanto I, Prijono S, Yani M. 2009. Distribution of rats at Lore Lindu National Park, Central Sulawesi, Indonesia. J Trop Biol Conserv 5:43-52.

Miller GS, Jr. 1912. Catalogue of the mammals of Western Europe (Europe exclusive of Russia) in the collection of the British Museum. London: British Museum (Natural History).

Miller GS Jr, Hollister N. 1921. Descriptions of sixteen new murine rodents from Celebes. Proc Biol Soc Wash 34:93-104.

Misonne X. 1969. African and Indo-Australian Muridae: Evolutionary trends. Ann Musée Roy Afr Centr Ser 8 Sci Zool 172:1-219.

Mulvaney J and Soejono RP. 1970. The Australian-Indonesian expodition to Suwalesi. AP 13:163-177.

Musser GG. 1984. Identities of subfossil rats from caves in southwestern Sulawesi. Mod Quat Re 8:61-94.

Musser GG. 2014. A systematic review of Sulawesi Bunomys (Muridae, Murinae) with the description of two new species. Bull Am Mus Nat Hist 392:1-313.

Musser GG, Durden LA. 2014. Morphological and geographic definitions of the sulawesian shrew rats Echiothrix leucura and E. centrosa (muridae, murinae), and description of a new species of sucking louse (Phthiraptera: Anoplura). Bull Am Mus Nat Hist 871:1-87.

Musser GG, Durden LA, Holden ME, Light JE. 2010. Systematic review of endemic Sulawesi squirrels (Rodentia, Sciuridae), with descriptions of new species of associated sucking lice (Insecta, Anoplura), and phylogenetic and zoogeographic assessments of sciurid lice. Bull Am Mus Nat Hist 339:1-260. 
Taxonomic Tapestries

Simons A, Bulbeck D. 2004. Late quaternary faunal successions in South Suwalesi, Indonesia. Mod Quat Re 18:167-190.

Tate GHH, Archbold R. 1935. Results of the Archbold Expeditions. No. 3. Twelve apparently new forms of Muridae (other than Rattus) from the IndoAustralian region. Am Mus Novit 803:1-9.

Thomas O. 1898. VIII. On the mammals collected by Mr. John Whitehead during his recent expedition to the Philippines with field notes by the collector. Trans Zool Soc Lond 14:377-414.

Van de Weerd A. 1976. Rodent faunas of the Mio-Pliocene continental sediments of the Teruel-Alhambra region, Spain. Utrecht Micropaleontol Bull, Special Publication 2:1-218.

Voss RS. 1988. Systematics and ecology of ichthyomyine rodents (Muroidea): Patterns of morphological evolution in a small adaptive radiation. Bull Am Mus Nat Hist 188:259-493.

Whitmore TC. 1984. Tropical rainforests of the Far East. Second edition. Oxford: Clarendon Press.

Whitten AJ, Mustafa M, Henderson GS. 1987. The ecology of Sulawesi. Yogyakarta: Gadjah Mada University Press. 
This text is taken from Taxonomic Tapestries: The Threads of Evolutionary, Behavioural and Conservation Research, edited by Alison M Behie and Marc F Oxenham, published 2015 by ANU Press, The Australian National University, Canberra, Australia. 